\title{
A partial braincase and other skeletal remains of Oligocene angel sharks (Chondrichthyes, Squatiniformes) from northwest Belgium, with comments on squatinoid taxonomy
}

\author{
Frederik H. Mollen ${ }^{1,5}$, Barry W.M. van Bakel ${ }^{2,3}$, John W.M. Jagt ${ }^{4}$ \\ ${ }^{1}$ Elasmobranch Research, Rehaegenstraat 4, 2820 Bonheiden, Belgium \\ ${ }^{2}$ Oertijdmuseum De Groene Poort, Bosscheweg 80, 5283 WB Boxtel, The Netherlands \\ ${ }^{3}$ Naturalis Biodiversity Center, P.O. Box 9517, 2300 RA Leiden, The Netherlands \\ ${ }^{4}$ Natuurhistorisch Museum Maastricht, de Bosquetplein 6-7, 6211 KJ Maastricht, The Netherlands \\ ${ }^{5}$ E-mail:frederik.mollen@gmail.com
}

Key words: chondrocranium, CT scanning, neurocranium, Pristiophorus, Squatina, vertebrae

\begin{abstract}
A detailed redescription of a chondrocranium from the basal Boom Clay Formation (Rupelian, Upper Oligocene) at the SVK clay pit, Sint-Niklaas (province of Oost-Vlaanderen, Belgium), previously assigned to the sawshark Pristiophorus rupeliensis, is presented. The chondrocranium is re-identified as that of an angel shark (Squatinidae), based on comparative anatomy of extant Squatina, inclusive of CT scans of Squatina africana, S. australis, S. dumeril, S. guggenheim and S. squatina, with different geographic distributions and representing all four angel shark clades as defined in a previous molecular study. Differential characters for chondrocrania listed in earlier accounts to discriminate angel shark species from the southwest Atlantic proved to be even more revealing when comparing angel sharks from different regions/clades. Despite this wide interspecific variation, the fossil chondrocranium compares well with modern Squatina, but differs in having a UUU-shaped ventral margin of the occipital region and rounded margins of the upper postorbital processes. The distal expansion of the upper postorbital processes present in modern species has not yet been observed in extinct squatinoids and might constitute a derived character for modern representatives only. Angel shark teeth and vertebrae are well known from the same basal deposit at the SVK clay pit, but Cenozoic squatinid taxonomy remains problematic. It is here discussed in detail for the Oligocene taxa S. angeloides, S. rupeliensis and S. beyrichi. For the time being, all SVK material is left in open nomenclature and referred to as Squatina sp.
\end{abstract}

\section{Contents}

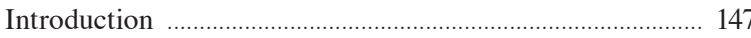

Material and methods .......................................................... 148

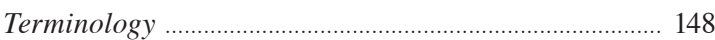

Institutional abbreviations .................................................. 150

Fossil material examined ..................................................... 150

Comparative Recent material .......................................... 150

Description of fossil chondrocranium ................................. 151

General outline ….................................................................. 151

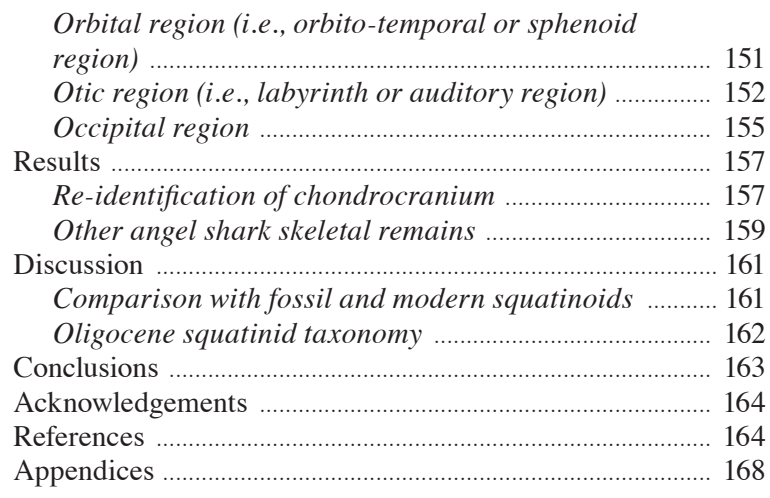

\section{Introduction}

Elasmobranch assemblages from the Boom Clay Formation (Rupelian, Upper Oligocene) have been studied in detail previously (e.g. Storms, 1894; Leriche, 1910; Steurbaut and Herman, 1978; Hovestadt and HovestadtEuler, 1995) and include those recovered from its basal gravel as exposed at the Scheerders van Kerchove's Verenigde Fabrieken (SVK) clay pit, near Sint-Niklaas, northwest Belgium (van den Bosch, 1981; Mollen, 2007). Recently, Herman et al. (2013) have presented an update of the faunal list of the Sint Niklaas Phosphorite Bed at this locality and added the occurrence of the sawshark Pristiophorus rupeliensis Steurbaut and Herman, 1978, on the basis of a partial, three-dimensionally preserved chondrocranium. The study of such rare cranial material is important, not only to faunal lists (see Mollen, 2010; Mollen and Jagt, 2012), but also for the phylogenetic analysis of elasmobranch fishes and timing of evolutionary diversification, in particular for taxa with conservative dental morphology through 


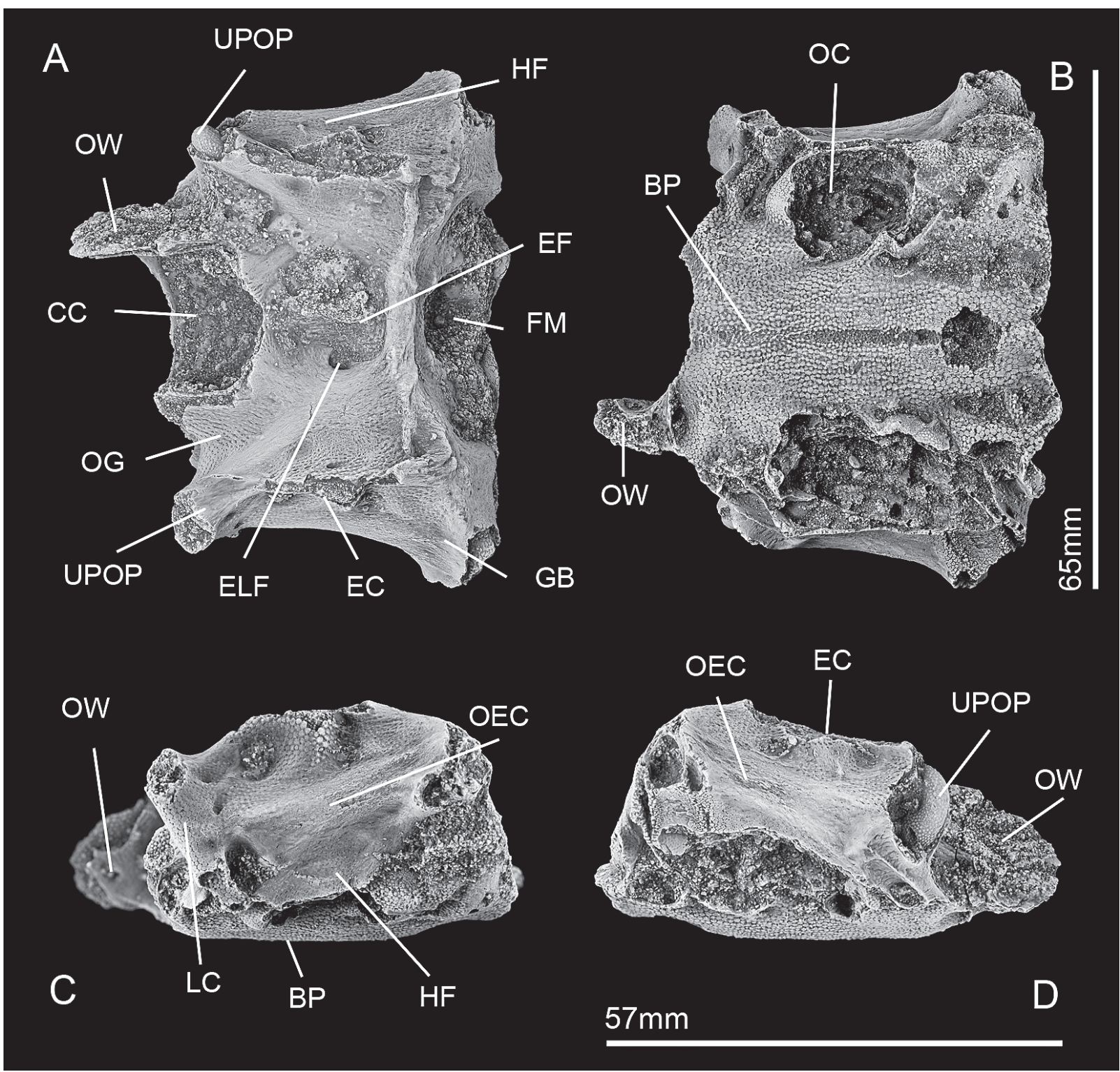

Fig. 1. Chondrocranium of Squatina sp. (IRScNB P.9485), Sint Niklaas Phosphorite Bed (Rupelian, Upper Oligocene), SVK clay pit (Oost-Vlaanderen, Belgium) in dorsal (A), ventral (B) and lateral (C-D) views. Abbreviations: BP, basal plate; CC, cranial cavity; EC, epiotic crest; EF, endolymphatic fossa; ELF, endolymphatic foramen; FM, foramen magnum; GB, glossopharygeal base; HF, hyomandibular facet; LC, lateral commissure; OEC, otic external canal; OC, otic capsule; OG, orbital groove; OW, orbital wall; UPOP, upper postorbital process.

time. Unfortuntately, Herman et al. (2013) did not provide detailed illustrations and descriptions of the SVK chondrocranium. Here we re-illustrate and redescribe this specimen in detail. In addition, our identification is based on comparative CT scans of modern elasmobranch taxa and literature data. Finally, implications for phylogeny and taxonomy are discussed.

\section{Material and methods}

\section{Terminology}

Topographical terminology and subdivision of chondrocranial structures differs markedly among elasmobranch researchers. Most relevant to the present study 


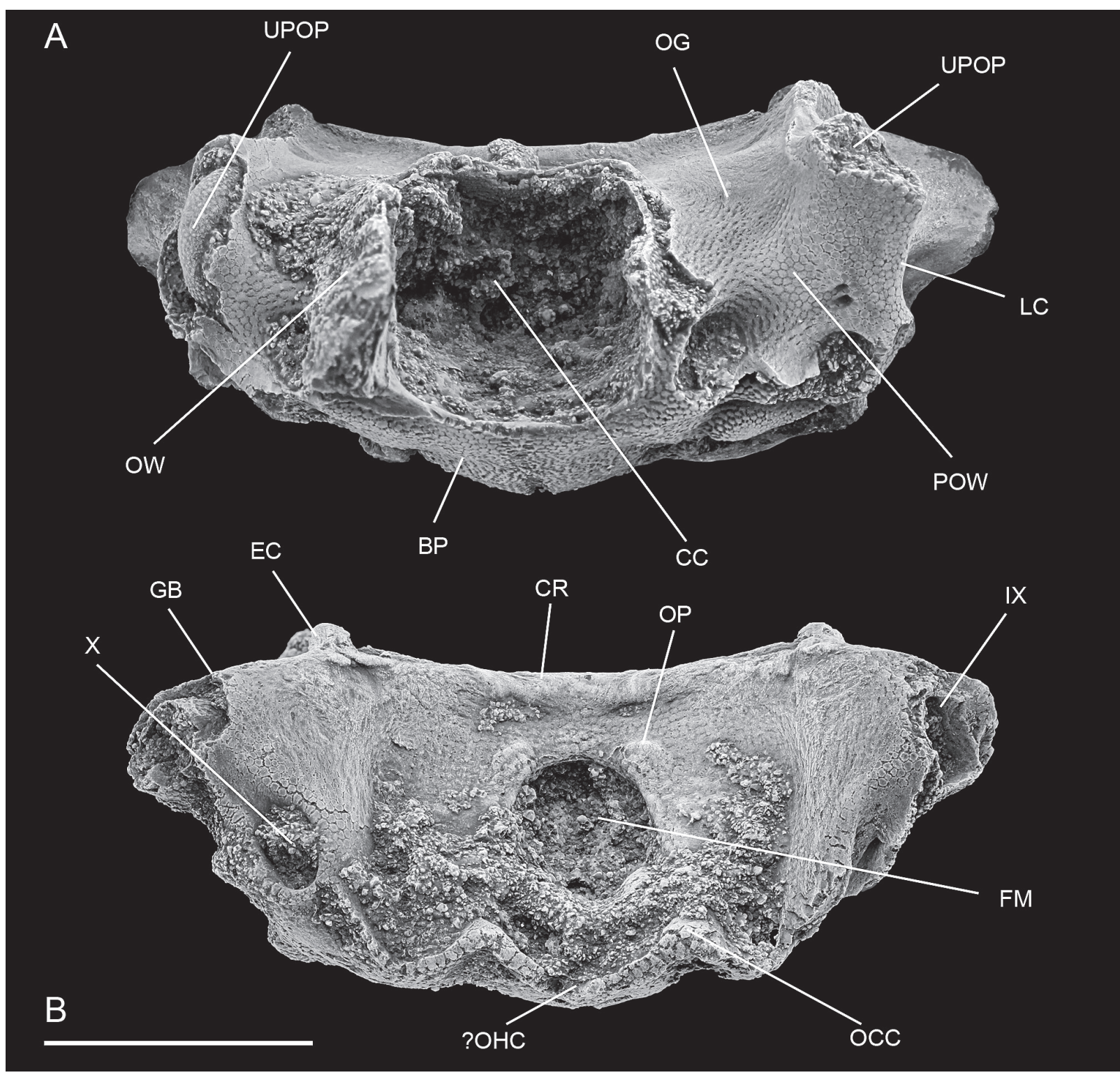

Fig. 2. Chondrocranium of Squatina sp. (IRScNB P.9485), Sint Niklaas Phosphorite Bed (Rupelian, Upper Oligocene), SVK clay pit (Oost-Vlaanderen, Belgium) in anterior (A) and occipital (B) views. Scale bar equals $20 \mathrm{~mm}$. Abbreviations: IX, glossopharygeal nerve foramen; X, vagus nerve foramen; BP, basal plate; CC, cranial cavity; CR, cranial roof; EC, epiotic crest; FM, foramen magnum; GB, glossopharygeal base; LC, lateral commissure; OCC, occipital condyle; OG, orbital groove; OHC, occipital hemicentrum; OP, occipital process; OW, orbital wall; POW, postorbital wall; UPOP, upper postorbital process.

are detailed descriptions of chondrocrania of Pristiophorus and Squatina by Hoffmann (1912) and Iselstöger (1937), respectively, who followed Gegenbaur (1872) in distinguishing four cranial regions, i.e. the (in original terminology) Occipital-, Labyrinth-, Orbital- and Ethmoïdal-Region. In contrast, Compagno (1988) divided the chondrocranium into seven struc- tural areas for descriptive purposes, i.e., rostrum, nasal capsules, cranial roof, basal plate, orbits, otic capsules and occiput. This subdivision does not necessarily correspond with embryonic origin, and thus might be somewhat arbitrary (see de Carvalho et al., 2012), but it does provide continuity for several definite structures in the postnatal stage such as the cranial roof and 
basal plate (basicranium) which would otherwise span both the orbital and otic (= labyrinth) region (Compagno, 1988). Whether or not such structures are present in the material studied often determines the cranial topographical nomenclature chosen. For instance, in comparative studies of modern angel shark chondrocrania, de Carvalho et al. (2012) and Vaz and de Carvalho (2013) followed Compagno (1988), but when describing fossil squatinoid chondrocrania (which are often incomplete), de Carvalho et al. (2008) adopted Gegenbaur's (1872) terminology, although they described the otic and occipital regions as one, i.e., the otico-occipital region. For the description of even more fragmentary squatinoid material (Guinot et al., 2012; Klug and Kriwet, 2013), no reference to cranial subdivisions was made. In the present specimen, almost the entire cranial roof and the anterior half of the basal plate are missing, but the posterior part of the orbital region, together with both otic and occipital regions, are exceptionally well preserved. Therefore, we prefer the classic fourfold division of Gegenbaur (1872), albeit in reverse order, i.e., snout first. Following Gegenbaur (1872: 30), the vagus nerve foramen (X) (Nervus vagus) separates the otic and occipital regions (see also Hoffmann, 1912: 277, Foramen $n$. vagi), making the occipital region extremely short in lateral view. In consequence, its description in the present paper is based mostly on the occipital view.

For the identification of cranial structures, including anatomical abbreviations, we mainly follow data presented by de Carvalho et al. (2012); for a complete list, reference is made to Appendix 1. Terminology used in previous accounts may differ significantly, which is why we add some terms in parentheses so as to make comparisons easier (see References).

\section{Institutional abbreviations}

Material examined in the present study is housed in the following collections: ERB, Elasmobranch Research Belgium, Bonheiden (Belgium); IRScNB, Institut Royal des Sciences Naturelles de Belgique, Brussels (Belgium); KZNSB, KwaZulu-Natal Sharks Board, Umhlanga (South Africa); MAB, Oertijdmuseum De Groene Poort, Boxtel (The Netherlands); NHMUK, The Natural History Museum, London (United Kingdom).

\section{Fossil material examined}

A partial chondrocranium (IRScNB P.9485; cast MAB 004705) and more than one hundred isolated verte- brae, including two with basiventrals partially preserved (all in private collections, except for IRScNB P.9486-9490) were recovered from the Sint Niklaas Phosphorite Bed at the SVK clay pit, 'new quarry' (sensu Janssen, 1981). The quarry, located southwest of Sint-Niklaas, province of Oost-Vlaanderen (Belgium), is now defunct.

Based on molluscan faunas, Marquet and Herman (2012) have recently described the 'Sint Niklaas Phosphorite Bed' as a new lithostratigraphic unit within the Ruisbroek Sand Member (Zelzate Formation, Tongeren Group), situated 2.5-3 metres below the base of the Belsele-Waas Clay Member (Boom Clay Formation, Rupel Group). Contrary to Marquet and Herman (2012), the phosphatic bed and overlying silty clay had earlier been considered to represent the basal and lowermost portion of the Belsele-Waas Clay Member, respectively, by Vandenberghe (1978) (see also Vandenberghe and Laga, 1986; Vandenberghe et al., 1998, 2002), a view adopted here. On calcareous nannofossil evidence (Steurbaut, 1986, 1992; Laga et al., 2002), the Belsele-Waas Clay Member has been dated as early to middle Rupelian (Oligocene) or zone NP23 (sensu Martini, 1971). For more detailed data on this locality and the section formerly exposed, reference is made to Mollen (2007).

The present chondrocranium was coated with ammonium chloride and photographed at different focal planes. Utilizing Helicon Focus software (Helicon Soft Ltd), composite and fully focused images were obtained.

\section{Comparative Recent material}

Fresh and complete specimens of a single species of Pristiophorus and five species of Squatina were examined for comparative purposes. Specimens of Squatina represent all four angel shark clades, as defined in a molecular study by Stelbrink et al. (2010) (for details, see Appendix 2). In view of the precarious conservation status of angel sharks, access to fresh specimens has become difficult. Consequently, all published illustrations of chondrocrania of Pristiophorus and Squatina are of importance; these are also listed in Appendix 2.

Prior to dissection, fresh and complete sharks were first photographed, measured, sexed, identified and sampled for muscular tissues that are kept deep frozen in 80 per cent ethanol at the Station de Biologie Marine (Concarneau, France). The identity of S. guggenheim Marini, 1936, a species often confused with the 
sympatric S. occulta Vooren and da Silva, 1991, was double checked and confirmed by DNA barcoding for all four specimens in the present study (courtesy of B. Stelbrink, March 2011).

After having dissected the jaws, the chondrocranium was separated from other skeletal parts using hot water maceration (see Stohler, 1945; Compagno, 1988), but those parts of the skin that could cause damage to the most fragile portions of the chondrocranium (i.e., the ethmoidal region) were left untouched. When packed in secure plastic bags and deep frozen, each chondrocranium was separately scanned in its natural position (see Mollen et al., 2012) using a Toshiba Aquilion One TSX-301C/2 medical CT scanner (courtesy of F. Hilte and J. Bauwens, ZNA hospitals, Antwerp, Belgium), with parameter settings varying from 120-135kVP, $150-300 \mathrm{~mA}$ and 0.5-2.0 mm slice thickness depending of size and calcification of each individual. Volume rendering was made possible through Vitrea Advanced fx and VitreaCore fx software (Toshiba Medical Systems Europe).

\section{Description of fossil chondrocranium}

\section{General outline}

The specimen is a partial, albeit exceptionally wellpreserved chondrocranium, its surface consisting mostly of prismatic, tessellated cartilage (Figs 1-2). The ethmoid region, which would have included the rostrum and the nasal capsules, together with the anterior half of the cranial roof and basal plate (BP, or basicranium), are missing, exposing the cranial cavity (CC) in anterior view (Fig. 2A). None of the broken surfaces are fresh; fracturing most probably occurred at an early stage of fossilisation. Although some structures are missing, the posteriormost part of the orbital region, together with both otic and occipital regions, are preserved three dimensionally. All together, the structures preserved have a more or less rectangular to trapezoidal outline in dorsal and ventral views, and appear flattened in latero-occipital view. A blackish phosphatic matrix fills the inner structures of the chondrocranium, obscuring some details of the external structures as well. Maximum chondrocranial width (as preserved), situated near the glossopharyngeal bases (GB), slightly exceeds the preserved length, and doubles the chondrocranial height. However, standard measurements for elasmobranch chondrocrania (see Compagno, 1988, Fig.
6.13), cannot be employed for incomplete specimens and matrix-covered structures. Therefore, preliminary measurements, relevant for this specimen, are depicted in Fig. 1B, D.

Orbital region (i.e., orbito-temporal or sphenoid region)

Together with the ethmoidal region, the anteriormost part of the orbital region is missing, including the supraorbital and suborbital crests. Although most of the paired medial orbital walls (OW) is lacking as well, the posteriormost portion of the right orbital wall is present, albeit covered with matrix (see Fig. 1A, D). In contrast, other parts of determinant structures of the orbit are well preserved, i.e., the left lateral commissure, both upper postorbital processes and orbital grooves.

The left lateral commissure (LC; 'FascialisSpange' of Iselstöger, 1937) is robust and well developed over its entire length. Its surface clearly consists of tessellated, prismatic cartilage. The distal margin of the lateral commissure is slightly concave in anterior view (Fig. 2A). In lateral view, the lateral commissure is oriented obliquely (Fig. 1C), inclining ventrally in posterior direction, and its anterior margin is rectilinear. In cross section, the distal portion of the lateral commissure is rounded. Dorsally, both lateral commissures were bounded by an upper postorbital process (UPOP; 'Processus postorbitalis' of Iselstöger, 1937). Although both upper postorbital processes have broken off, each leaving a clear fracture, their bases are well preserved, especially the left one (Fig. 2A). Unfortunately, because of this, the exact length of the upper postorbital process cannot be determined. A tessellated cartilage structure, well flattened laterally, is pressed into the base of the remaining right upper postorbital process. In lateral view, this structure is relatively tall and has a rounded anterior margin (see Fig. 1D). Because of its unique position and general shape, it appears to be the distalmost portion of the right upper postorbital proces. As suggested by the fracture near the ventral portion of the left lateral commissure, lower postorbital processes (LPOP) were most likely present as well, although they are not preserved. The lateral commissure, together with at least the upper postorbital process, and most likely also the lower ones, forms a robust postorbital wall (POW) (Fig. 2A). In dorsal view, the preserved parts of orbital and postorbital wall have a concave outline anteriorly, forming the posterior part of a large, well-marked 


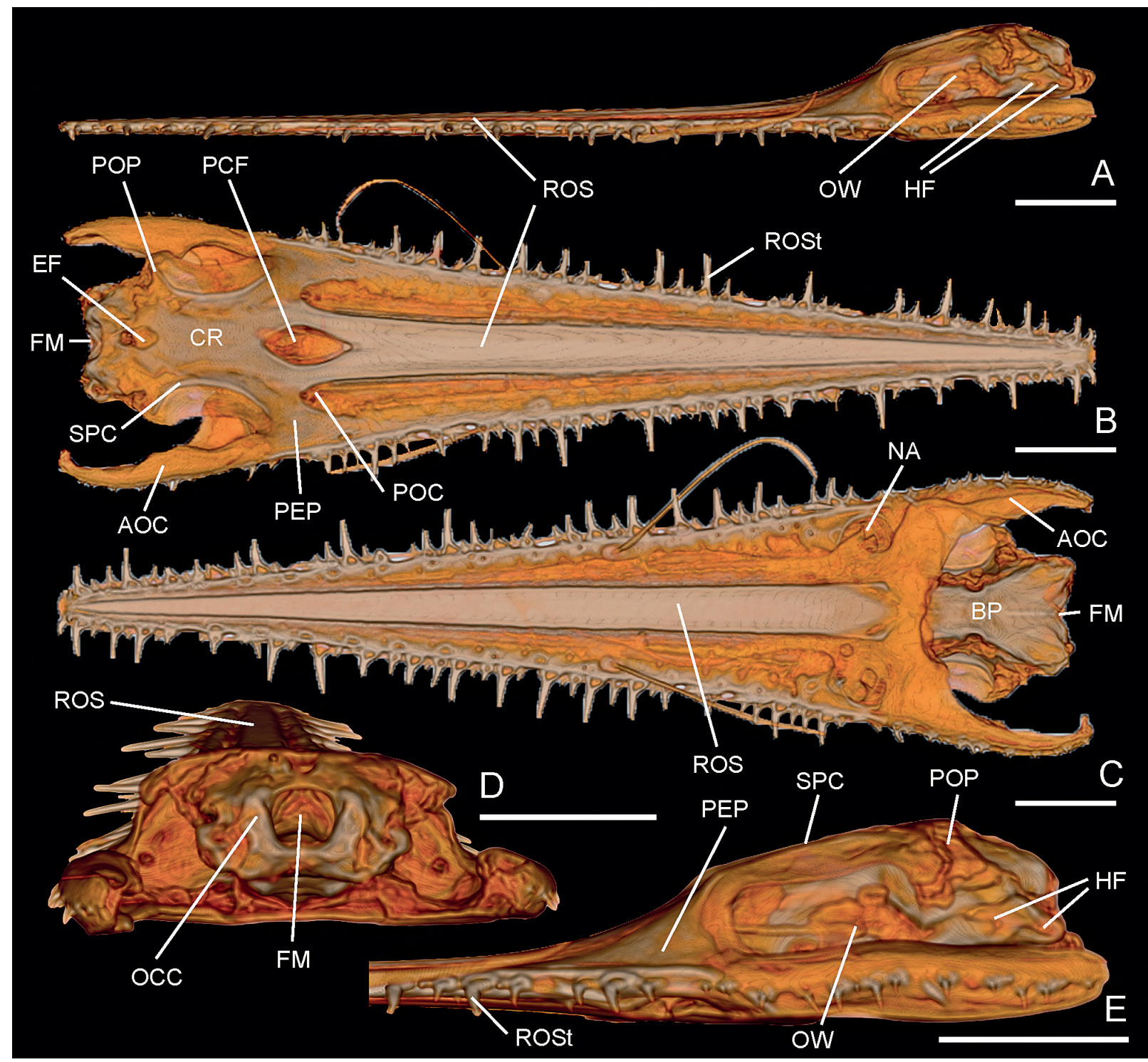

Fig. 3. Recent Pristiophorus nudipinnis Günther, 1870, female, $830 \mathrm{~mm}$ TL, Tasman Sea, Australia (ERB 1058), 3D-volume rendering of chondrocranium using CT scanning in lateral (A, E), dorsal (B), ventral (C) and occipital (D) views. Scale bars equal 20 mm. Abbreviations: AOC, antorbital cartilage; BP, basal plate; CR, cranial roof; EF, endolymphatic fossa; FM, foramen magnum; HF, hyomandibular facet; NA, nasal aperture; OCC, occipital condyle; OW, orbital wall; PCF, precerebral fossa; PEP, preorbital process; POC, preorbital canal; POP, postorbital process; ROS, rostrum; ROSt, rostral teeth; SPC, supraorbital crest.

orbital groove (OG; 'Schädellücke' of Iselstöger, 1937). In lateral view, the orbital groove is oriented obliquely, inclining ventrally in anterior direction, i.e., opposite to the inclination of the lateral commissure. In dorsal view, the posterior margin of the orbital groove almost reaches as far as the anterior margin of the endolymphatic foramen (see otic region). The surface of the orbital grooves was smooth (as seen in the left OG in our specimen); they would have accommo- dated the orbital processes of the palatoquadrates, moving through the orbital groove when opening the mouth.

\section{Otic region (i.e., labyrinth or auditory region)}

The otic region, which is separated from the orbital and occipital region by the posterior margin of the lateral commissure and vagus nerve foramen, respec- 


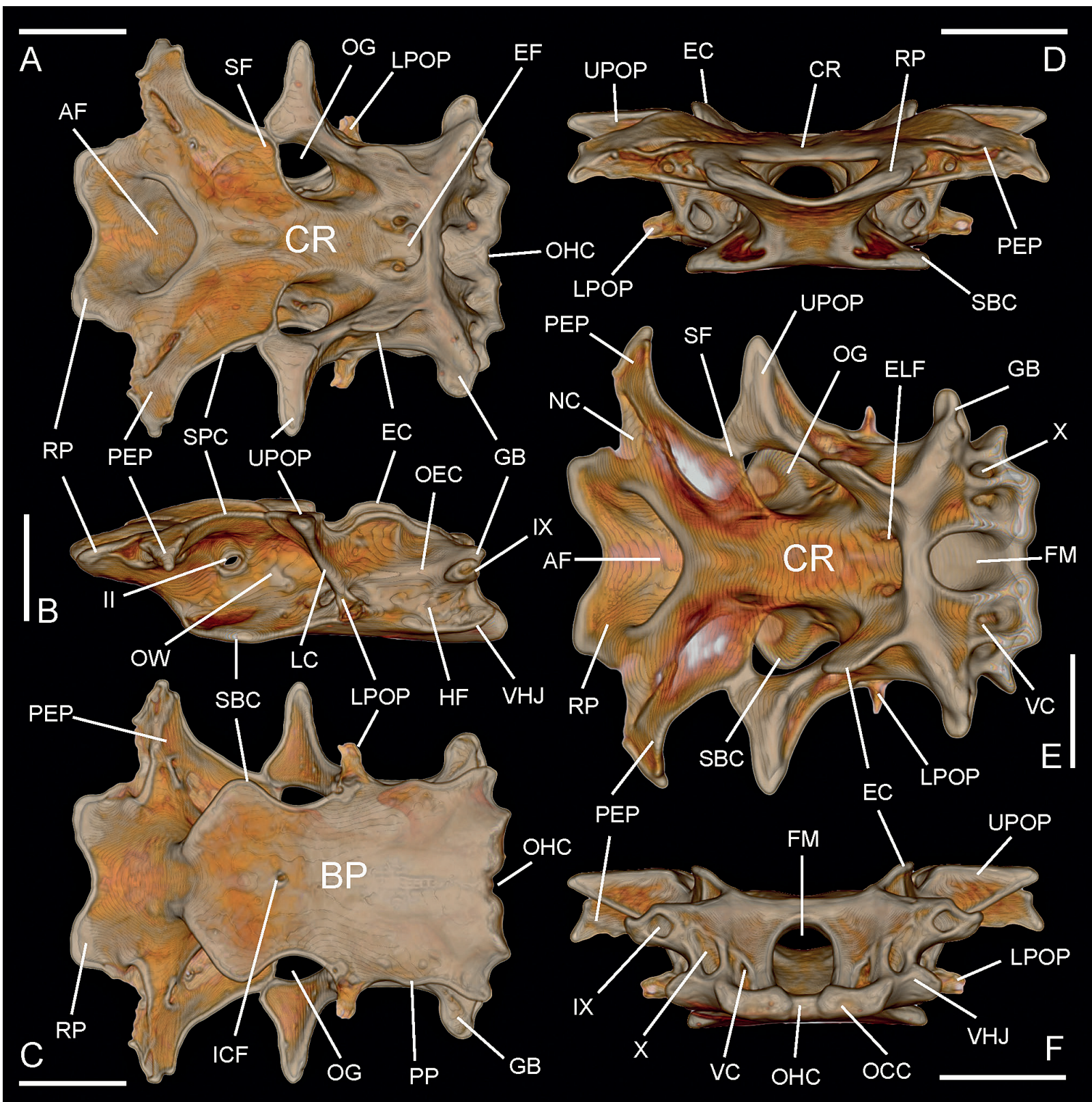

Fig. 4. Recent Squatina africana Regan, 1908, male, 820 mm TL, southwest Indian Ocean (ERB 0971), 3D-volume rendering of chondrocranium using CT scanning in dorsal (A), lateral (B), ventral (C), anterior (D), dorso-occipital (E) and occipital (F) views. Scale bars equal $20 \mathrm{~mm}$. Abbreviations: II, optic nerve foramen; IX, glossopharygeal nerve foramen; X, vagus nerve foramen; AF, anterior fontanelle; BP, basal plate; CR, cranial roof; EC, epiotic crest; EF, endolymphatic fossa; ELF, endolymphatic foramen; FM, foramen magnum; GB, glossopharygeal base; HF, hyomandibular facet; ICF, internal carotid artery foramen; LC, lateral commissure; LPOP, lower postorbital process; NC, nasal capsule; OCC, occipital condyle; OEC, otic external canal; OG, orbital groove; OHC, occipital hemicentrum; OW, orbital wall; PEP, preorbital process; PP, pterotic process; RP, rostral projection; SBC, suborbital crest; SF, supraorbital flange; SPC, supraorbital crest; UPOP, upper postorbital process; VC, posterior vein foramen; VHJ, ventral margin of hyoid junction.

tively, is almost complete and well preserved, representing most of the present specimen. In lateral view, the otic region is elongated and divided over its entire length, by a well-marked, horizontal ridge of the otic external canal (OEC; ' $\beta$ ' of Iselstöger, 1937), which borders the dorsal margin of a large and relatively 


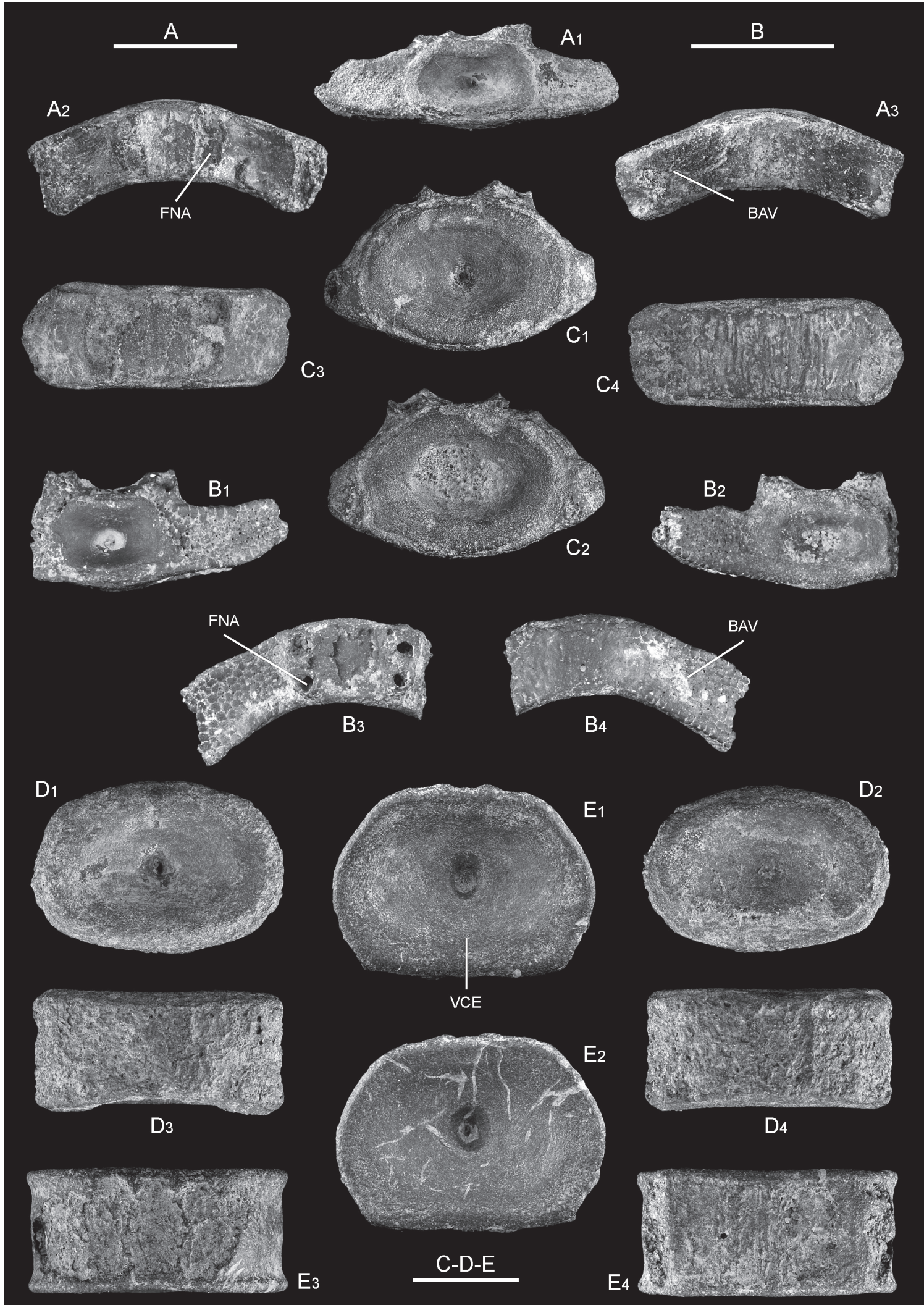


uniform hyomandibular facet (HF) (see Fig. 1C). In dorsal view, the otic region is bordered over its entire length laterally by a parallel pair of longitudinally oriented epiotic crests (EC). The right epiotic crest ('sphenopterotic ridge' of Shirai, 1992b) is less well preserved than the left one, but does show a clear outline of the epiotic crest base in dorsal view, which is anteriorly bounded by the base of the upper postorbital process, and widest in its median portion (see Fig. 1A). Also in dorsal view, the posterior end of both epiotic crests are bounded by a continuous, well-marked and rectilinear transverse crest ('ridged, posterior tectum' of de Carvalho et al., 2008: 480) which is more robust in its mid-portion (= otic-occipital junction). Just anterior to the transverse crest, and in between the otic capsules, is the endolymphatic fossa, situated within a shallow depression. The endolymphatic fossa (EF; 'parietal fossa' of Maisey, 1983) is wider than long, with a rounded posterior margin. However, most of the endolymphatic fossa is filled with matrix, covering the lymphatic foramina, except for the left endolymphatic foramen (ELF), which is relatively large, with its centre situated at the anterior and distalmost margins of the endolymphatic fossa. In ventral view, the basal plate, except for the otic capsules (OC), is well preserved, its surface consisting of tessellated, prismatic cartilage. Although the basal plate is not preserved ventrally to the otic capsules, much of their margins is still intact, rectangular to oval in appearance, and protruding as if they were bulging. As a result, the otic capsules and medial portion of the basal plate are separated by a pair of longitudinal depressions running from the anterior margin of the $\mathrm{OC}$ bulge towards the occipital region. In cross section, the basal plate is slightly convex between both grooves. In its mid-portion, a well-marked medial, longitudinal groove is present (Fig. 1B).

\section{Occipital region}

The occipital region, well preserved in the SVK specimen, is more or less dorso-ventrally flattened and widest near the glossopharyngeal bases (see Fig. $2 \mathrm{~B})$. It is separated from the otic region by the vagus nerve foramen (following Gegenbaur, 1872; Hoffmann, 1912), making the occipital region extremely short in lateral view. In this view, the occipital region is oriented obliquely, inclining ventrally in posterior direction (Fig. 1C-D). As a result, the occipital region can also be observed in dorsal view, albeit under an angle. In this view, the dorsal margin of the occipital region is more or less concave between the posterior ends of the epiotic crests in general outline, but rectilinear in its mid-portion (which equals the width of the foramen magnum). Here, the dorsal margin of the occipital region is completely merged with the midportion of the transverse crest, making it very robust in its median part (Fig. 1A). In occipital view, the dorsal margin of the occipital region is slightly concave between the epiotic crests, and slightly overhanging posteriorly in its mid-portion (= otic-occipital junction), forming a pair of short, near-horizontal grooves dorsal to the large foramen magnum. The foramen magnum (FM) is partially filled and covered with matrix, especially near its ventral margin, but appears to have had an oval, vertically oriented shape (Fig. 2B). Matrix also covers the regions lateral to the foramen magnum, thus obscuring possible posterior vein foramina. A pair of oval occipital processes $(\mathrm{OP})$ are present near the dorsal margin of the foramen magnum, slightly ventral to the horizontal grooves formed by the overhanging otic-occipital junction; their dorsal margins are more pronounced than the ventral ones. The foramen magnum is flanked by at least one pair of openings for the vagus nerve $(\mathrm{X})$ which are situated posterior to the foramen magnum in dorsal view (see Fig. 2B). Glossopharyngeal bases (GB) and glossopharyngeal nerve foramina (IX) are present, but are only partially preserved. As a result of longitudinal grooves in the basicranium (see description of otic region), the ventral margin of the occipital region is UUU shaped, and protrudes posteriorly. It consists of tesselated, prismatic cartilage, forming a complete, robust, yet not swollen ridge, with the possible exception of its portion ventral to the foramen magnum which is slightly damaged, leaving a broken, faintly oval, wedge-shaped structure (for an interpretation, see Results and Discussion).

Fig. 5. Vertebrae of Squatina sp., Sint Niklaas Phosphorite Bed (Rupelian, Upper Oligocene), SVK clay pit (Oost-Vlaanderen, Belgium) from head (A-C; IRScNB P.9486-9488) to trunk (D-E; IRScNB P.9489-9490) regions. Subscripts 1-4 represent the articular surface(s), and dorsal and ventral views of each vertebrate, respectively. Scale bars equal $10 \mathrm{~mm}$. Abbreviations: BAV, basiventral process; FNA, articular foramen for neural arch; VCE, vertebral centre. 


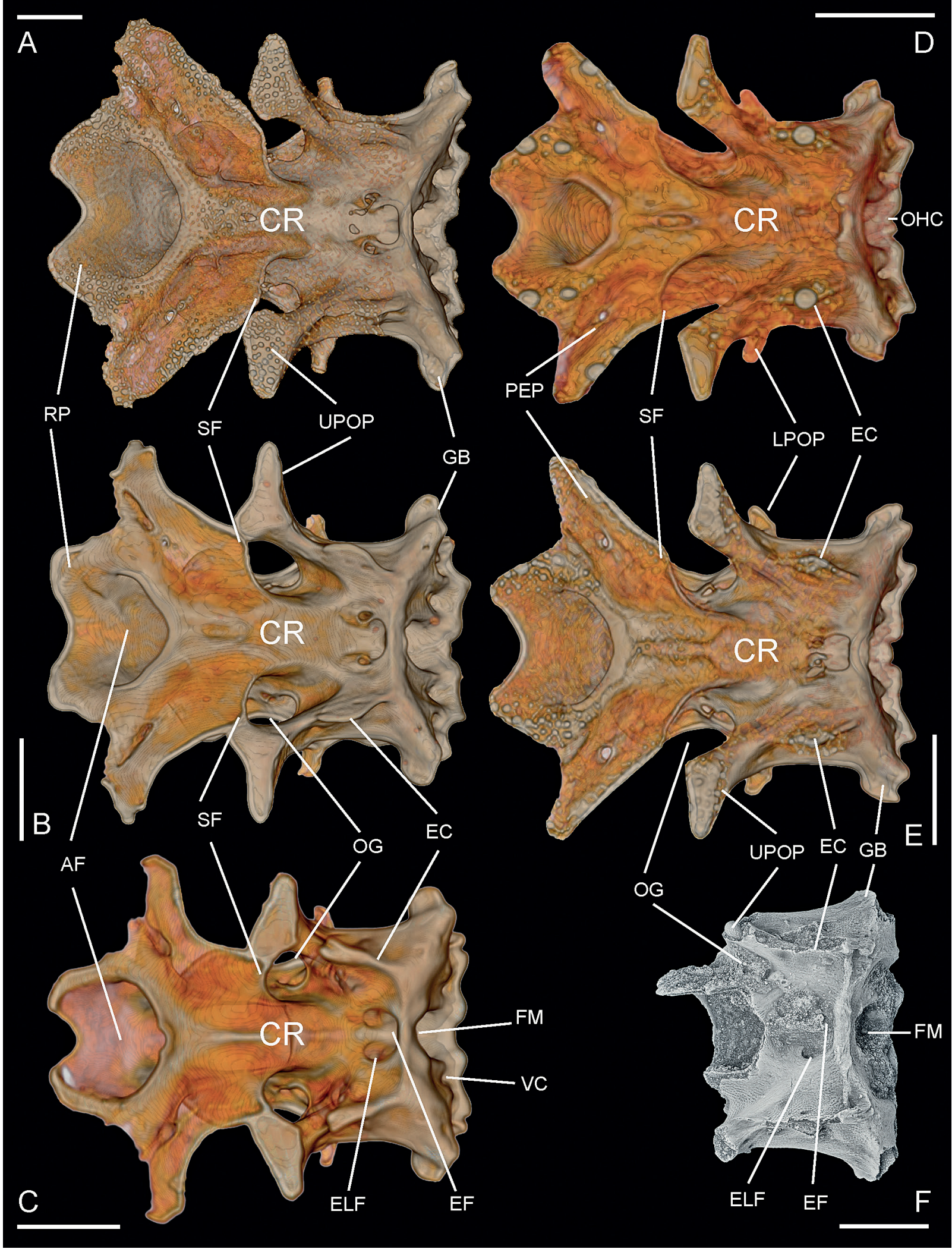




\section{Results}

\section{Re-identification of chondrocranium}

Herman et al. (2013: 20; Pl. 11, Fig. 1A-B; Pl. 12, Fig. 1A-B; non Pl. 53, Fig. 1 - see other angel shark skeletal material below) were the first to record this unique SVK chondrocranium. Although no cranial regions, nor anatomical structures, were identified, the authors assigned it to Pristiophorus rupeliensis Steurbaut and Herman, 1978. Their identification was based on a process of elimination, starting with five possible genera that matched the 'very massive, granulous and flat morphology' that they observed, i.e., Squatina Duméril, 1806, Pristiophorus Müller and Henle, 1837, Pliotrema Regan, 1906a, Anoxypristis White and MoyThomas, 1941 and Pristis Linck, 1790. These genera represent a group of dorsoventrally flattened chondrichthyan fishes that are closely related according to morphological evidence (Shirai, 1992a, b; 'hypnosqualean group'; also de Carvalho, 1996; de Carvalho and Maisey, 1996; 'Hypnosqualea'). However, molecular evidence contests this phylogeny (Douady et al., 2003; Winchell et al., 2004; Heinicke et al., 2009; Vélez-Zuazo and Agnarsson, 2011), leaving interrelationships unresolved to date (see also Claeson and Hilger, 2011).

Herman et al. (2013: 20) immediately ruled out the possibility that the SVK chondrocranium belonged to that of Squatina, because 'the posterior cranial aperture was circular', whilst they assumed the foramen magnum to be horizontally oval like the vertebral centra in Squatina (see Herman et al., 2013: 22). They also excluded Anoxypristis and Pliotrema, because no prePliocene examples were known to them from the fossil record, leaving only the sawfish Pristis or sawshark Pristiophorus. In support of their preliminary identification they referred to what appeared to them to be 'the beginning of one nasal cartilaginous extension', suggesting the remains of an elongated, tooth-bearing rostrum. On the basis of radiographs of taxidermied specimens of the two remaining genera (see Herman et al., 2013: Pls 81-82), they favoured assignment of the SVK specimen to the genus Pristiophorus, but did not provide any argumentation. In view of the fact that only a single species of Pristiophorus was known from the European Oligocene, Herman et al. (2013) identified the chondrocranium from Sint-Niklaas as $P$. rupeliensis.

We agree with the observation of Herman et al. (2013) that the foramen magnum of Pristiophorus is round (see Fig. 3D; compare Hoffmann, 1912: Pl. 16, Fig. 28; Shirai, 1992b: Pl. 21, Fig. D), whereas that of Squatina is more or less oval (Figs 4F, 7A-E; compare Iselstöger, 1937: Pl. 6, Fig. E; Shirai, 1992b: Pl. 21, Fig. C). However, they erroneously assumed the foramen magnum of the angel shark to be horizontally oval, similar to that of their vertebral centra, while, in fact, it is vertically oval. We also contest their observation that the foramen magnum was perfectly round in the present specimen; we note it to be vertically oval. However, the ventral portion is matrix covered, obscuring its complete outline, thus making it an unreliable character in this case.

In extant Pristiophorus, the occipital region is oriented vertically in lateral view ('vertikalen Ebene' of Hoffmann, 1912) (see Shirai, 1992a: Fig. 4E; 1992b: Pl. 22 , Fig. E), with the foramen magnum flanked by a pair of well-developed occipital condyles ('halbmondförmigen Gelenkhöckern' of Jaekel, 1890; 'Gelenkkopf' of Hoffmann, 1912) that join ventrally in several species of sawshark (Fig. 3D; compare Jaekel, 1890; Shirai, 1992b: Pl. 21, Fig. D = all P. nudispinnis), but not in all (see Hoffmann, 1912: Pl. 16, Fig. $28=$ P. japonicus). In contrast, the mid-portion of the occipital region in the SVK specimen is oriented obliquely, and the foramen magnum is not flanked by any occipital condyles. In addition, Pristiophorus possesses a double-socketed hyomandibular facet (Fig. 3A, E; compare Compagno, 1973, 1977; Shirai, 1992b: Pl. 14, Fig. C), whilst the SVK specimen presents a single, anteriorly extended hyomandibular facet that is limited dorsally by a wellmarked, horizontal ridge of the otic external canal (Fig. 1C-D). In our view, the 'beginning of one nasal

Fig. 6. Interspecific variations in Recent Squatina spp. (A-E) in dorsal view, compared to the fossil specimen (F; IRScNB P.9485). Recent chondrocrania are presented as 3D-reconstructions using CT scanning of S. squatina (A; ERB 1029), S. africana (B; ERB 0971), S. australis (C; ERB 0514), S. dumeril (D; ERB 1026) and S. guggenheim (E; ERB 0881). Species represent the European/North African/Asian (A), South African (B), Australian (C) and North/South American (D-E) clades as defined by Stelbrink et al. (2010). Scale bars equal $20 \mathrm{~mm}$. Abbreviations: AF, anterior fontanelle; CR, cranial roof; EC, epiotic crest; EF, endolymphatic fossa; ELF, endolymphatic foramen; FM, foramen magnum; GB, glossopharygeal base; LPOP, lower postorbital process; OG, orbital groove; OHC, occipital hemicentrum; PEP, preorbital process; RP, rostral projection; SF, supraorbital flange; UPOP, upper postorbital process. 


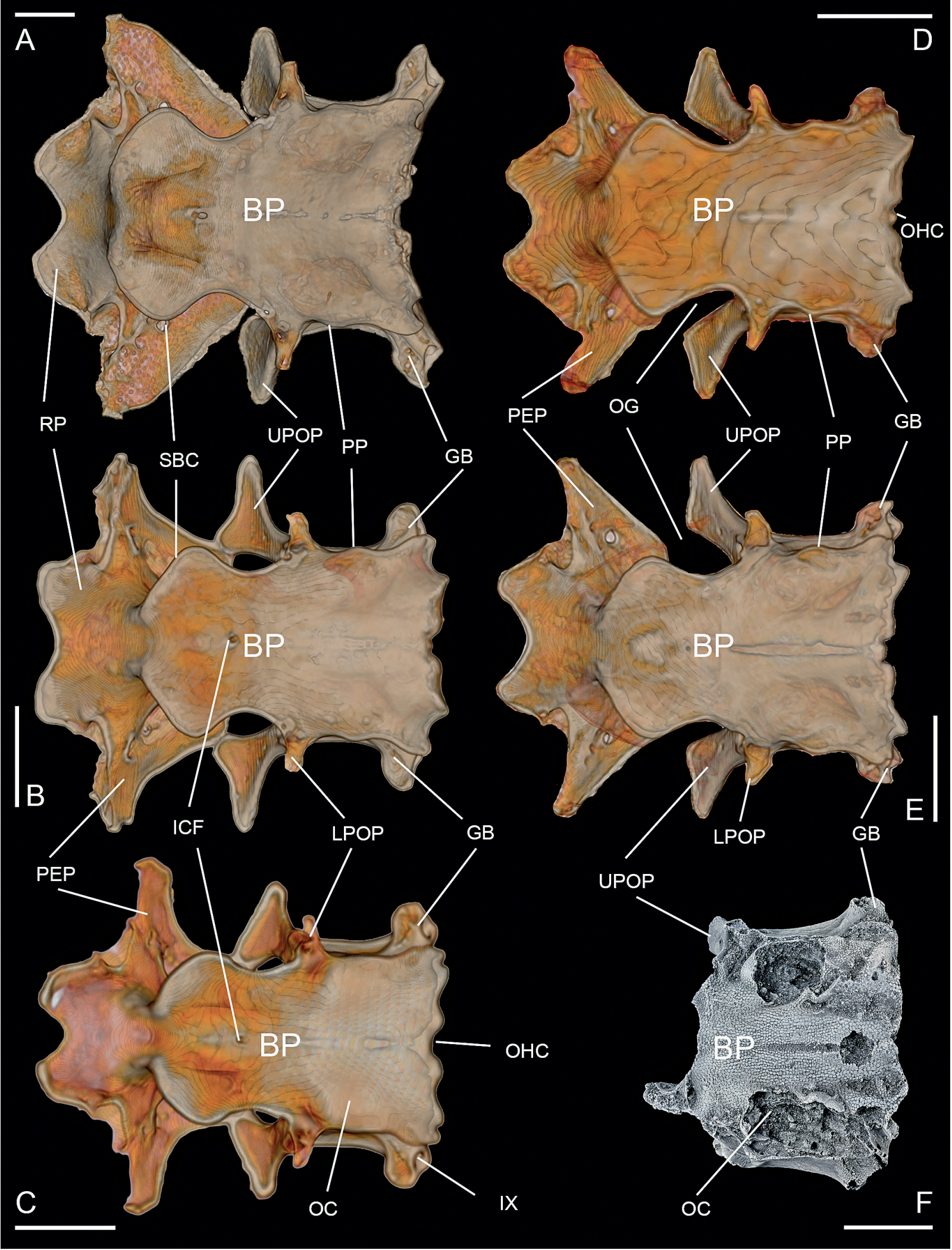


cartilaginous extension', considered by Herman et al. (2013) to present the base of an elongated rostrum as in Pristiophorus, rather is the posteriormost portion of the right orbital wall, which is present in all chondrichthyan fishes. Consequently, it is obvious that Herman et al. (2013) considered this structure to be situated near the junction of the ethmoid and orbital regions, but in fact it is near the junction of the orbital and otic regions. The otic region is exceptionally elongated in the SVK specimen, which might explain why the otic and orbital regions were confused.

An elongated otic region such as the one observed in the SVK chondrocranium, is a derived character found in Squatina (de Carvalho et al., 2008). In addition, a complete postorbital wall (with enclosed jugular canal), lateral commissure, fully chondrified upper postorbital process, orbital groove accommodating the movement of long orbital process on the palatoquadrate ('Schädellücke für den Processus palatobasalis des Oberkiefers' of Iselstöger, 1937) and an anteriorly extended, single hyomandibular facet, all present in the SVK chondrocranium, also are diagnostic of squatinids (see e.g., Holmgren, 1941; Maisey, 1983, 1985, 2007; de Carvalho et al., 2008). Considering this unique set of characters, we reject its earlier identification as Pristiophorus, and reassign the SVK specimen to Squatina.

\section{Other angel shark skeletal remains}

Our identification of the SVK chondrocranium as that of an angel shark does not come as a surprise, because teeth of Squatina are well known from Rupelian (Oligocene) strata in Belgium. They are common in the Berg and Kerniel members (both Bilzen Formation) (Baut and Génault, 1999), as well as in the Sint Niklaas Phosphorite Bed at the SVK clay pit (van den Bosch, 1981; FHM, pers. obs.), but become extremely rare in the overlying silty and clayey horizons of the Boom Clay Formation. Teeth and vertebrae of Squatina from the Boom Clay were recorded by Storms (1894), but such elements were not encountered in bulk sampling by van den Bosch (1981), Steurbaut and Herman (1978), Hovestadt and Hovestadt-Euler (1995), nor are they represented in the ERB collections.

The Sint Niklaas Phosphorite Bed, a specific lithostratigraphic unit underlying the Boom Clay Formation, illustrates deposition on a sandy and shallow sea floor, colonised by very rich faunas, including burrowing decapod crustaceans, worms, molluses and small teleost fish (Vandenberghe et al., 2002; van Bakel et al., 2003, 2009; Marquet and Herman, 2012). Modern angel sharks are often found hiding in muddy and sandy bottoms, feeding on a variety of small invertebrates and small bony fish, caught by ambush attack (Iselstöger, 1944; Compagno, 1984). With this in mind, the sea floor must have been a perfect habitat at the time of sedimentation of this unit, until the arrival of new, phosphate-laden water masses that led to its cementation and deposition of the deeper-water Boom Clay Formation, much less rich in such fossils (see Vandenberghe et al., 2002: Fig. 6). For the Sint Niklaas Phosphorite Bed, van den Bosch (1981) published a preliminary list comprising nine elasmobranch taxa, including teeth of Squatina which accounted for as much as 15.8 per cent of all material found, a percentage comparable to that of material housed in the ERB collections and in other, private collections (see Mollen, 2007). An updated elasmobranch faunal list for this horizon is presented in Appendix 3.

In addition to these teeth and the chondrocranium, the Sint Niklaas Phosphorite Bed has yielded more than one hundred isolated vertebrae of Squatina; their centra ranging between 8 and $32 \mathrm{~mm}$ in width, 6 and $22 \mathrm{~mm}$ in height and 5 and $14 \mathrm{~mm}$ in thickness. Unique to angel sharks (see e.g., Hasse, 1876, 1877, 1882; Ridewood, 1921), is the fact that these vertebral centra (VCE) are more or less horizontally oval to hexagonal, wider than tall, showing concentric lamellae in cross section (i.e., tectospondylous), and varying along the vertebral column in the position and development of basiventrals which allows head, trunk and tail vertebrae to be distinguished (see Fig. 5; compare Natanson and Cailliet, 1990). Two of the SVK vertebrae (IRScNB P.9486 and

Fig. 7. Interspecific variations in Recent Squatina spp. (A-E) in ventral view, compared to the fossil specimen (F; IRScNB P.9485). Recent chondrocrania are presented as 3D-reconstructions using CT scanning of S. squatina (A; ERB 1029), S. africana (B; ERB 0971), S. australis (C; ERB 0514), S. dumeril (D; ERB 1026) and S. guggenheim (E; ERB 0881). Species represent the European/North African/Asian (A), South African (B), Australian (C) and North/South American (D-E) clades as defined by Stelbrink et al. (2010). Scale bars equal $20 \mathrm{~mm}$. Abbreviations: IX, glossopharygeal nerve foramen; BP, basal plate; GB, glossopharygeal base; ICF, internal carotid artery foramen; LPOP, lower postorbital process; OC, otic capsule; OG, orbital groove; OHC, occipital hemicentrum; PEP, preorbital process; PP, pterotic process; RP, rostral projection; SBC, suborbital crest; UPOP, upper postorbital process. 


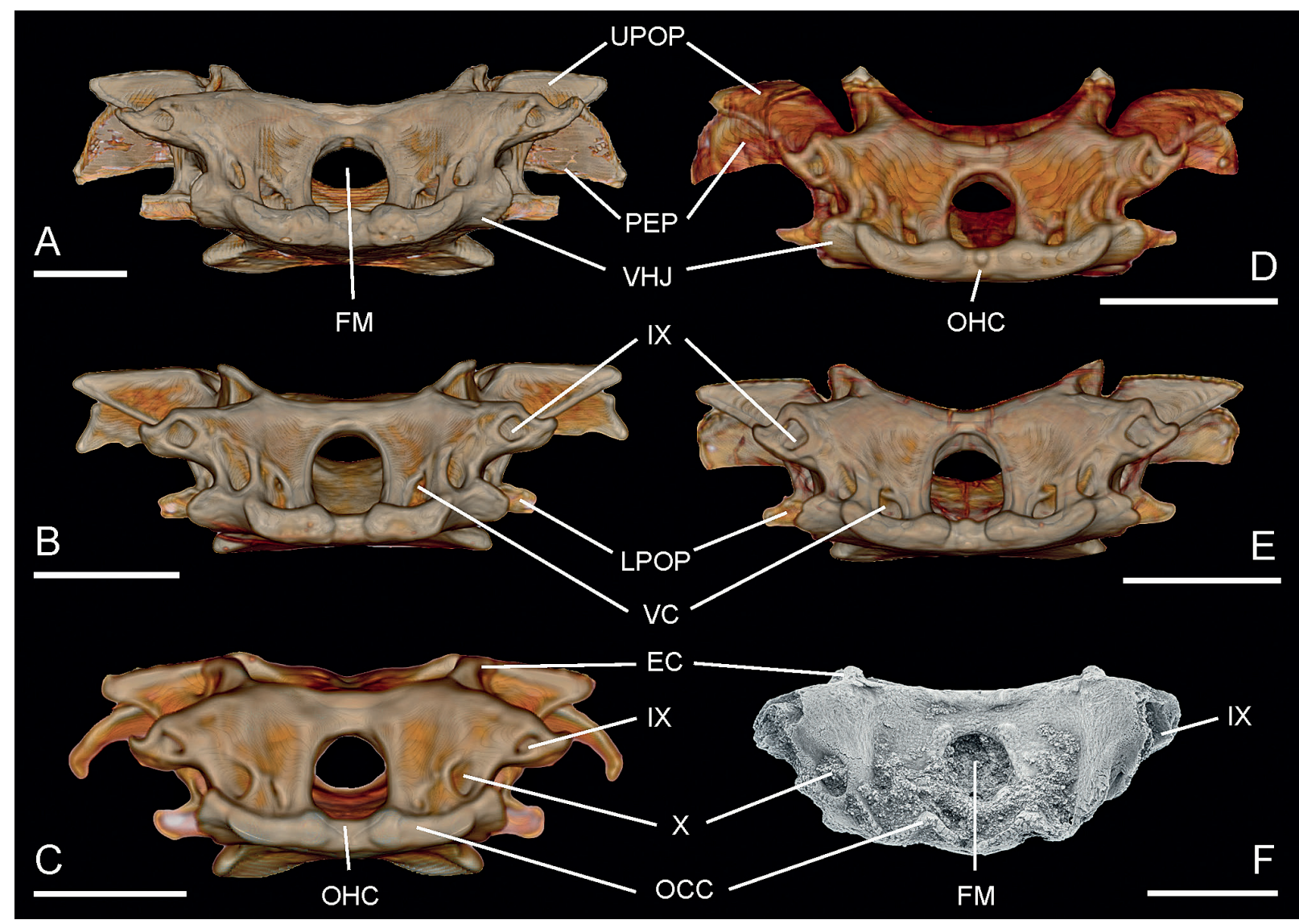

Fig. 8. Interspecific variations in Recent Squatina spp. (A-E) in occipital view, compared to the fossil specimen (F; IRScNB P.9485). Recent chondrocrania are presented as 3D-reconstructions using CT scanning of S. squatina (A; ERB 1029), S. africana (B; ERB 0971), S. australis (C; ERB 0514), S. dumeril (D; ERB 1026) and S. guggenheim (E; ERB 0881). These represent the European/North African/Asian (A), South African (B), Australian (C) and North/South American (D-E) clades as defined by Stelbrink et al. (2010). Scale bars equal $20 \mathrm{~mm}$. Abbreviations: IX, glossopharygeal nerve foramen; X, vagus nerve foramen; EC, epiotic crest; FM, foramen magnum; LPOP, lower postorbital process; OCC, occipital condyle; OHC, occipital hemicentrum; PEP, preorbital process; UPOP, upper postorbital process; VC, posterior vein foramen; $\mathrm{VHJ}$, ventral margin of hyoid junction.

P.9487; Fig. 5A-B, respectively) retain robust and elongated basiventrals, albeit in part. In modern angel sharks, this is diagnostic of the 4-10th most anterior vertebrae (Melouk, 1948; Claeson and Hilger, 2011). One of these (IRScNB P.9487; Fig. 5B) was erroneously identified by Herman et al. (2013: 191, Pl. 53, Fig. 1) as the posterior portion of a chondrocranium of Squatina; the vertebral centre was misinterpreted as the foramen magnum.

In dorsal and ventral views, the first vertebra in modern Squatina is elongated and trapezoidal in shape, with an anterior facet that is significantly smaller than the posterior one (see e.g., Melouk, 1948; Claeson and Hilger, 2011). The robust basiventrals are oriented more or less perpendicularly to the vertebral longitudinal axis. Together with the small anterior facet of the vertebral centrum, they form the counterpart of the articulating occipital hemicentrum and swollen occipital condyles, respectively, as present at the ventral margin of the chondrocranial occipital region. In contrast, vertebrae IRScNB P.9486-9487 are not elongated, but rather more or less rectangular in dorso-ventral view, having anterior and posterior vertebral centrum facets of equal size, with basiventrals oriented posteriorly. Additionally, the basiventrals have anterior facets that are more or less flat (vs concave counterparts for the occipital condyles), and most likely represent the 2nd-4th anteriormost vertebrae, corresponding to a much smaller individual in comparison to the SVK chondrocranium. 


\section{Discussion}

\section{Comparison with fossil and modern squatinoids}

Squatinoids are represented by two monotypical families (Squatinidae, Pseudorhinidae) that comprise Squatina Duméril, 1806 and Pseudorhina Jaekel, 1898, respectively. The family Pseudorhinidae has been erected only recently by Klug and Kriwet (2013) to accommodate the latter genus and its constituent species, P. acanthoderma (Fraas, 1854), P. alifera (von Münster, 1842) and P. frequens (Underwood, 2002). Stratigraphically, these species range from the upper Oxfordian to the lower Tithonian (Upper Jurassic; see Cappetta, 2012). In contrast, all post-Jurassic squatinoids, inclusive of modern angel sharks, have been assigned to Squatina (Squatinidae) (see e.g., Guinot et al., 2012). Klug and Kriwet (2013) estimated the date of the origin of (identifiable characters of) Squatiniformes to lie between 181.74 and 156.2 Ma, and that of Squatinidae to be between 157.59 and $114 \mathrm{Ma}$, representing 'soft' maximum and 'hard' minimum age constraints, respectively. The early age of radiation of extant angel shark species was dated at $33.17 \pm 9.85 \mathrm{Ma}$ by Stelbrink et al. (2010: Table 6), which overlaps with the Rupelian age of the SVK specimen. In this respect, this particular specimen is of interest in our understanding of modern squatinid diversity as well.

Pseudorhina (i.e., Pseudorhinidae) differs from Squatina (i.e., Squatinidae) by a large number of characters, including a longer anterior fontanelle with a less rounded posterior margin, less concave lateral capsular walls of the otic region and more laterally oriented postorbital processes. Of these three cranial features, only the upper postorbital processes are retained in the SVK chondrocranium. Although not complete in our specimen, the bases of both upper postorbital processes are oriented more anteriorly, which is a morphological feature typical of Squatina (see de Carvalho et al., 2008; Klug and Kriwet, 2013), and consistent with what could be expected for a squatinoid of Oligocene (i.e., post-Jurassic) age. Other characters diagnostic of Pseudorhina comprise proportionally larger vertebral hemicentra, comparably shorter and more tightly connected basiventral processes and a broad labial protuberance ('apron' of Cappetta, 1987) of teeth not supported by roots (Claeson, 2008; de Carvalho et al., 2008; Klug and Kriwet, 2013). The relative size of vertebral hemicentra is difficult to assess in the isolated vertebrae from the SVK clay pit, but the anterior vertebrae found at the level that yielded the chondrocra- nium display relatively robust and long basiventrals (see Fig. 5A-B), which make assignment to Squatina most likely. In addition, squatinoid teeth from the Sint Niklaas Phosphorite Bed are diagnostic of Squatina, in having a slender apron that is supported by the root.

Although chondrocrania of modern angel sharks are generally conservative, de Carvalho et al. (2012) listed several differential characters in three species of Squatina from the southwest Atlantic (i.e., S. argentina (Marini, 1930), S. guggenheim and S. occulta). These include rostral projections, anterior fontanelle, supraorbital crest, upper postorbital process, lower postorbital process, otic capsules, suborbital crest and pterotic process. These diagnostic features prove to be even more revealing when comparing species of Squatina from different geographic origins, which correlates to different clades based on molecular evidence (Stelbrink et al., 2010) (see Figs 6-8). In spite of the fact that the SVK chondrocranium is closely similar to those of modern angel sharks, two morphological features might actually fall outside the range of interspecific variation seen in modern Squatina. In the latter, the ventral margin of the occipital region is rectilinear and the occipital hemicentrum is flanked by a pair of swollen occipital condyles that are oriented horizontally, with only their lateral margins slightly bent dorsally (see Fig. 8A-E). In contrast, the ventral margin of the occipital region of the SVK specimen is UUU-shaped and not swollen (see Fig. 8F). Although a broken, slightly oval, wedge-shaped structure is visible ventral to the foramen magnum, there is no clear indication of an occipital hemicentrum in this specimen. However, in modern angel sharks this structure easily detaches in fetal specimens (Claeson and Hilger, 2011) and is only weakly calcified in adults (de Carvalho et al., 2008) which might explain its absence in the SVK specimen. Secondly, the anterior margin of the upper postorbital process is distally expanded in all modern angel sharks (de Carvalho et al., 2012; the present study), forming a completely or nearly closed orbital groove in those species that present a well-developed supraorbital flange (see Figs 6-7; compare de Carvalho et al., 2012). Although the upper postorbital processes are not completely preserved in the SVK specimen, remains of this structure seem rounded in both dorso-ventral and lateral views and thus are not expanded. As a result, the orbital groove was most likely not fully closed. Such horizontal expansion is absent in Jurassic Pseudorhina, and has not yet been observed in Cretaceous species of Squatina either (see Guinot et al., 2012; NHMUK P.12213). Consequently, 
the distal expansion of the anterior margin of the upper postorbital proces might well represent a derived character for Recent angel sharks only, or at least post-Oligocene ones.

As a result, the UUU shape of the ventral margin of the occipital region, combined with rounded margins of the upper post orbital process ( $v s$ distally expanded), might justify the erection of a new genus to accommodate the SVK chondrocranium. However, in view of the fact that the fossilisation process might have had an impact on the shape of the ventral margin of the occipital region and of the occipital condyles in particular (e.g., shrunk, abraded), and the upper postorbital processes are not completely preserved, we prefer to await the discovery of additional material and/or pieces of evidence (e.g., on brain nerve foramina). Unfortunately, the inner structures of the phosphatic chondrocranium have proved impossible to penetrate by the medical CT scanner available to us.

\section{Oligocene squatinid taxonomy}

The fossil record of Squatina comprises at least 35 nominal species, most of them published in the $1800 \mathrm{~s}$ (Cappetta, 2006). Some are based on (partial) skeletons, but most descriptions rely on isolated teeth or vertebrae only. For isolated material, differential characters are rarely provided and interspecific variation has not been studied. In other cases, new species have been erected merely on the basis of stratigraphic provenance of the material. The naming of new so-called chronospecies, without proper differential diagnosis, was very common at the time, especially for taxa whose (dental) morphology had been quite conservative over time, such as Squatina. Therefore, taxonomic revisions of fossil angel sharks (e.g. Guinot et al., 2012) are called for, particularly post-Mesozoic species. In some cases, assignment of isolated teeth and vertebrae to species is fraught with difficulties, and might even prove impossible (Cappetta, 2012; Herman et al., 2013; the present study). Authors often opt to leave angel shark material in open nomenclature (Squatina sp.), in particular when this originates from strata of Cenozoic age (see Klug and Kriwet, 2013).

However, Oligocene angel shark teeth have often been identified as S. angeloides Van Beneden, 1873 (e.g., Nolf, 1988; Reinecke et al., 2001; Cicimurri and Knight, 2009; Génault, 2012). The same holds true for teeth of Squatina from the SVK clay pit (see van den Bosch, 1981). The original species description by Van Beneden (1873: 384) was based on a collection of un- associated vertebrae from an undocumented locality in Belgium (current whereabouts unknown), not illustrated and described extremely briefly as follows, 'Squatina angeloïdes. Van Ben. Nous avons des vertèbres en assez grand nombre pour reconstituer une colonne vertébrale plus ou moins complète. Ces vertèbres sont surtout reconnaissable au corps, qui est plus large que haut.' (We have a large number of vertebrae to reconstruct a vertebral column that is more or less complete. These vertebrae are easy to identify, trunk vertebrae in particular, that are wider than tall). Van Beneden's description is quite remarkable as new chondrichthyan taxa are rarely based on skeletal elements because such are seldom preserved, especially in strata of Cenozoic age (Mollen, 2010; Mollen and Jagt, 2012). Moreover, isolated skeletal material and, in particular vertebrae, often are undiagnostic, making it unsuitable for describing new taxa. In Van Beneden's case, we agree that the vertebrae (which are wider than tall) are diagnostic of the genus Squatina, but not of its constituent species (see e.g., Hasse, 1876, 1877, 1882; Ridewood, 1921). Van Beneden, probably aware of this shortcoming, did not provide differential characters to discriminate among species of Squatina. In view of this, we consider $S$. angeloides to have been based merely on stratigraphic data. Three other angel shark species have been described from Oligocene deposits, all postdating $S$. angeloides, namely $S$. beyrichi Noetling, 1885, S. rupeliensis Daimeries, 1889 and $S$. crecelii Weiler, 1922. The last-named species was based on teeth, whereas the other two were erected on the basis of isolated vertebrae.

Storms (1894) was the first to describe and illustrate teeth (and vertebrae) of Squatina from the Belgian $\mathrm{Ru}-$ pelian (R2c, equalling the Boom Clay Formation, Upper Oligocene), and assigned them to $S$. angeloides, assuming the vertebrae of Squatina described by Van Beneden had originated from the same level. Although the description provides detailed differential diagnoses with fossil as well as modern angel shark species (at the time, this was very progressive), evidence that teeth and vertebrae stem from the same species of Squatina is lacking. The geographic distribution of modern species of Squatina overlap extensively (Stelbrink et al., 2010), and the material from the Belgian Oligocene might well represent more than a single species.

Unlike Storms (1894), we do not consider the stratigraphic origin of $S$. angeloides to be beyond doubt. In fact, Van Beneden did not record any stratigraphic data in his description of $S$. angeloides, nor can the stratigraphic context be deduced from the text beyond 
doubt. Although Van Beneden's chapter in Patria Belgica was more or less in reversed stratochronological order, beginning with the Pliocene and ending with the Cretaceous, and most of these sections included references to faunal lists from the same stratum that had been published previously, no clear subdivisions were made in the text, nor was a species list for the Oligocene provided. Moreover, in the text, several species were stated to occur at more than one level, making it unclear which one Van Beneden was discussing at the time. This holds true especially for $S$. angeloides.

Although rare, most of the elasmobranch skeletal material known from the Belgian Cenozoic originates from the Boom Clay Formation (see Leriche, 1910), supporting Storms's (1894) assumption. However, in Leriche's series of papers on fossil fishes from the Belgian Cenozoic, vertebrae of Squatina were recorded from all time intervals; Paleocene (Leriche, 1902: 17; Pl. 1, Figs 21-22), Eocene (Leriche, 1905: 96), Oligocene (Leriche, 1910: 251-252) and Mio-Pliocene (Leriche, 1926: 382, Fig. 163-163a; 383, Fig. 164-164b). A fossil angel shark vertebra donated by Van Beneden to Hasse (1877: 349; 1882: 135), was consistently mislabelled as 'Pliocaen (Terrain rupel(l)ien)'. Daimeries (1889) noted this conflicting label in Hasse (1882), and favoured the 'Terrain rupelien', yet failed to provide arguments for his choice. Subsequently, Daimeries (1889) described this particular specimen as $S$. rupeliensis, a species erroneously reported by Cappetta (2006: 201) as originating from the Eocene, apparently unaware of Van Beneden's (1873) description.

In conclusion, the original description of $S$. angeloides is extremely poor and based on vertebrae of uncertain stratigraphic provenance that are not diagnostic at the species level. The material was not illustrated and its current whereabouts are unknown. In view of the fact that criteria stipulated by the code (ICZN, art. 12.1) are barely met, we consider $S$. angeloides to be a nomen nudum, and thus unavailable. The same applies for $S$. rupeliensis the description of which suffers the same shortcomings. However, Daimeries (1889) referred to material mentioned by Hasse (1882). Although a name can be made available by indication (ICZN, art. 12.1), requirements of art. 12.2. are not met. In contrast, Noetling (1885) did provide a proper description of $S$. beyrichi, inclusive of illustrations and stratigraphic origin of the vertebrae. Although this name is available according to the code, we consider it to be a nomen dubium because angel shark vertebrae are not diagnostic at the species level; in doing so we agree with Cappetta (2006), who rejected the name.

\section{Conclusions}

After re-examination and reinterpretation of the SVK skeletal remains from the Sint Niklaas Phosphorite Bed (Rupelian, Upper Oligocene), we have come to the following main conclusions:

1. The SVK chondrocranium, previously assigned to the sawshark Pristiophorus rupeliensis, should be reassigned to an angel shark, a taxon well represented by teeth and vertebrae at the same stratigraphic level, i.e., the basal deposit of the Boom Clay Formation, constituting $>15$ per cent of the elasmobranch assemblage. Consequently, we propose to delete $P$. rupeliensis from the faunal list as long as no other diagnostic material of this species is forthcoming. In contrast to the Sint Niklaas Phosporite Bed, angel shark remains are extremely rare in the overlying clayey facies of the Boom Clay Formation, which is explained by changing habitat conditions and prey diversity, unfavourable to squatinids. An updated elasmobranch list of the Sint Niklaas Phosphatic Bed is presented in Appendix 3.

2. Differential characters of chondrocrania listed in previous accounts for the discrimination of angel shark species from the southwest Atlantic have proved to be even more revealing when comparing angel sharks from different geographic origins, which correlates to different clades as defined in molecular studies. Considering these interspecific variations, the SVK chondrocranium compares well with those of modern Squatina, but differs in having a UUU-shaped ventral margin of the occipital region and rounded upper postorbital process margins. The distal expansion of the upper postorbital processes that are present in modern Squatina, has not been observed in Jurassic, nor in Cretaceous squatinoids to date, and might thus well represent a derived character for modern angel sharks.

3. The erection of a new generic and specific name for the SVK chondrocranium should await further consideration so as to avoid the introduction of junior synonyms (i.e., conspecific isolated teeth may already have been described in the past). More material (e.g., with upper post orbital processes better preserved) and/or future studies on the inner structures of the SVK chondrocranium (e.g., brain, nerves etc.) may turn out more conclusive, but examination of the latter was not possible with the medical CT scanner available to us. Thus, we retain the SVK chondrocranium in open nomenclature for now and refer to it as Squatina sp. 
4. The taxonomy of extinct angel sharks remains problematic. Squatinids present a very conservative (tooth) morphology, which has resulted in the description of many so-called chronospecies that lack (reliable) differential diagnoses. Moreover, several species have been described on isolated vertebrae that are diagnostic only at the generic level, making them unsuitable for species discrimination. In the present study, we consider the Oligocene $S$. angeloides and $S$. rupeliensis to be nomina nuda (i.e., unavailable) and S. beyrichi to be a nomen dubium. Re-evaluation of all other squatinid nominal species is urgently needed, especially those of Cenozoic age. In view of this, the isolated vertebrae in the present study are also left in open nomenclature, and referred to as Squatina sp.

\section{Acknowledgements}

We thank J. Herman (Beigem) and P. De Schutter (Opwijk) for bringing the SVK chondrocranium to our attention; L. Anthonis (Grobbendonk), B. D’Haeze (Evergem), B. Gijsen (Berlaar), T. Lambrechts (Heist-op-den-Berg) and E. Wille (Wuustwezel) for access to other SVK skeletal remains; K. Post (Het Natuurhistorisch, Rotterdam) for providing replica casts of the SVK chondrocranium; S. Iglésias (Muséum national d'Histoire naturelle, Concarneau), A. Graham (The Commonwealth Scientific and Industrial Research Organisation, Hobart), J. Mello and L. Natanson (National Marine Fisheries Service, Woods Hole, Massachusetts), S. Wintner (KZNSB, Umhlanga Rocks), J. Haelters, S. Bruaux and W. Wouters (IRScNB, Brussels) for making comparative material available; B. Stelbrink (Museum für Naturkunde, Berlin) for DNA barcoding; F. Hilte and J. Bauwens (ZNA hospitals, Antwerp) for CT scanning; D. Huber (University of Tampa, Tampa, Florida) and M. Dean (Max-PlanckInstitut für Kolloid- und Grenzflächenforschung, Potsdam) for sharing CT data; J. Schierenberg (Amsterdam) for providing rare items of literature; J. Maisey (American Museum of Natural History, New York) for fruitful discussions; T. Cook (Penn State University, Erie) and three anonymous reviewers for their constructive comments on an earlier version of the typescript.

\section{References}

Agassiz L. 1833-1844. Recherches sur les poissons fossiles, 3. Neuchâtel: Petitpierre.

Andreae A. 1892. Weitere Beiträge zur Kenntniss des Oligozäns im Elsaß. Mitteilungen der Geologischen Landesanstalt von Elsass-Lothringen 3: 105-122.

Ayres WO. 1859. Descriptions of fishes. Proceedings of the California Academy of Sciences (1)2: 25-32.

Bakel BWM van, Jagt JWM, Fraaije RHB. 2003. Ciliopagurus obesus, a new species of Oligocene hermit crab from northwest Belgium. Cainozoic Research 2 (for 2002): 109-116.
Bakel BWM van, Artal P, Fraaije RHB, Jagt JWM. 2009. A new early Oligocene crab (Decapoda, Brachyura, Dromiacea) from northwest Belgium, with comments on its palaeobiology. Geologica Belgica 12: 45-57.

Baut J-P, Génault B. 1999. Les elasmobranches des Sables de Kerniel (Rupélien), à Gellik, Nord Est de la Belgique. Memoirs of the Geological Survey of Belgium 45: 1-61.

Berg LS. 1958. System der rezenten und fossilen Fischartigen und Fische. Berlin: VEB Deutscher Verlag der Wissenschaften.

Bleeker P. 1858. Vierde bijdrage tot de kennis der ichthyologische fauna van Japan. Acta Societatis Regiae Scientiarum Indo-Neêrlandicae 3: 1-46.

Bonaparte CL. 1840. Iconografia della fauna italica per le quattro classi degli animali vertebrati. Tomo III. Pesci. Roma: Tipografia Salviucci.

Bosch M van den. 1981. Verslag van het onderzoek van het onderste deel van de Boom Klei Formatie, Rupelien, in de kleigroeve bij Sint-Niklaas, België (met bijzondere aandacht voor de elasmobranchen-associaties in het oudste Rupelien). Annalen van de Koninklijke Oudheidkundige Kring van het Land van Waas 84: 41-48.

Capapé C, Roux C. 1980. Etude anatomique du neurocrâne, de la ceinture pelvienne et des ptérygiopodes des Squatinidae (Pisces, Pleurotremata) des côtes tunisiennes. Bulletin du Muséum national d'Histoire naturelle (A)(4)2: 1161-1180.

Cappetta H. 1987. Chondrichthyes II. Mesozoic and Cenozoic Elasmobranchii. Pp. 1-193 in: Schultze H.-P., ed., Handbook of Paleoichthyology 3B. Stuttgart/New York: Gustav Fischer.

Cappetta H. 2006. Elasmobranchii Post-Triadici (Index specierum et generum). Pp. 1-472 in: Riegraf W., ed., Fossilium Catalogus, I: Animalia 142. Leiden: Backhuys Publishers.

Cappetta H. 2012. Chondrichthyes. Mesozoic and Cenozoic Elasmobranchii: teeth. Pp. 1-512 in: Schultze H.-P., Kuhn, O, eds, Handbook of Paleoichthyology 3E. München: Friedrich Pfeil.

Carvalho MR de. 1996. Higher-level elasmobranch phylogeny, basal squaleans, and paraphyly. Pp. 35-62 in: Stiassny MLJ, Parenti LR, Johnson GD, eds, Interrelationships of fishes. New York: Academic Press.

Carvalho MR de, Faro C, Gomes UL. 2012. Comparative neurocranial morphology of angel sharks from the south-western Atlantic Ocean (Chondrichthyes, Elasmobranchii, Squatinidae): implications for taxonomy and phylogeny. Acta Zoologica 93: 171-183.

Carvalho MR de, Kriwet J, Thies D. 2008. A systematic and anatomical revision of Late Jurassic angel sharks (Chondrichthyes: Squatinidae). Pp. 469-502 in: Arratia G, Schultze H.-P., Wilson MVH, eds, Mesozoic Fishes 4, Homology and phylogeny. München: Friedrich Pfeil.

Carvalho MR de, Maisey JG. 1996. Phylogenetic relationships of the Late Jurassic shark Protospinax Woodward 1919 (Chondrichthyes: Elasmobranchii). Pp. 9-46 in: Arratia G, Viohl G, eds, Mesozoic Fishes, Systematics and Paleoecology. München: Friedrich Pfeil.

Casier E. 1966. Faune ichthyologique du London Clay. London: British Museum (Natural History).

Cicimurri DJ, Knight JL. 2009. Late Oligocene sharks and rays from the Chandler Bridge Formation, Dorchester County, South Carolina, USA. Acta Palaeontologica Polonica 54: 627-647. 
Claeson KM. 2008. Angel shark fetuses reveal new information about fossil juvenile relatives. Journal of Vertebrate Paleontology 28 (Supplement to no. 3): 64A.

Claeson KM, Hilger A. 2011. Morphology of the anterior vertebral region in elasmobranchs: special focus, Squatiniformes. Fossil Record 14: 129-140.

Compagno LJV. 1973. Interrelationships of living elasmobranchs. Pp. 15-61 in: Greenwood PH, R.S. Miles RS, Patterson C, eds, Interrelationships of fishes. Zoological Journal of the Linnean Society 53, Supplement 1.

Compagno LJV. 1977. Phyletic relationships of living sharks and rays. Pp. 303-322 in: Northcutt RG, ed., Recent advances in the biology of sharks. American Zoologist 17.

Compagno LJV. 1984. Sharks of the world, an annotated and illustrated catalogue of shark species known to date. Part 1. Hexanchiformes to Lamniformes. FAO Fisheries Synopsis 125: 1-249.

Compagno LJV. 1988. Sharks of the order Carcharhiniformes. Princeton: Princeton University Press.

Cuvier G. 1829. Le règne animal, distribué d'après son organisation, pour servir de base à l'histoire naturelle des animaux et d'introduction à l'anatomie comparée. Nouvelle édition, revue et augmentée. Paris: Déterville.

Daimeries A. 1889. IV. - Notes ichthyologiques. Annales de la Société royal malacologique de Belgique, Séances (4)4: 5-10.

Douady CJ, Dosay M, Shivji MS, Stanhope MJ. 2003. Molecular phylogentic evidence refuting the hypothesis of Batoidea (rays and skates) as derived sharks. Molecular Phylogenetics and Evolution 26: 215-221.

Duméril C. 1806. Zoologie analytique ou méthode naturelle de classification des animaux, rendue plus facile à l'aide de tableaux synoptiques. Paris: HL Perronneau.

Fraas O. 1854. Squatina acanthoderma, der Meerengel von Nusplingen. Zeitschrift der deutschen geologischen Gesellschaft 6: 782-799.

Gegenbaur C. 1872. Untersuchungen zur vergleichenden Anatomie der Wirbelthiere. Drittes Heft. Das Kopfskelet der Selachier, als Grundlage zur Beurtheilung der Genese des Kopfskeletes der Wirbelthiere. Leipzig: Wilhelm Engelmann.

Génault B. 2012. Vertebrata (Chondrichthyes). CD-ROM in Lozouet P, ed., Stratotype Stampien. Paris, Mèze: Muséum national d'Histoire naturelle, Biotope.

Guinot G, Underwood CJ, Cappetta H, Ward DJ. 2012. Squatiniformes (Chondrichthyes, Neoselachii) from the Late Cretaceous of southern England and northern France with redescription of the holotype of Squatina cranei Woodward, 1888. Palaeontology 55: 529-551.

Günther A. 1870. Catalogue of the fishes in the British Museum, 8. Catalogue of the Physostomi, containing the families Gymnotidae, Symbranchidae, Muraenidae, Pegasidae, and of the Lophobranchii, Plectognathi, Dipnoi, Ganoidei, Chonderopterygii, Cyclostomata, Leptocardii, in the British Museum. London: British Museum (Natural History).

Hamdy AR. 1960. Dorsal fontanelles in selachian neurocrania. Nature 185: 939.

Hasse C. 1876. Die fossilen Wirbel. Morphologisches Jahrbuch 2: 449-477.

Hasse C. 1877. Die fossilen Wirbel. Morphologisches Jahrbuch 3: $328-351$
Hasse C. 1882. Das natürliche System der Elasmobranchier auf Grundlage des Baues und der Entwicklung ihrer Wirbelsäule. Eine morphologische und paläontologische Studie. Besonderer Theil 2. Jena: Gustav Fischer.

Heinicke MP, Naylor GJP, Hedges SB. 2009. Cartilaginous fishes (Chondrichthyes). Pp. 320-327 in: Hedges SB, Kumar S, eds, The Timetree of Life. New York: Oxford University Press.

Herman J, Van Waes H, Doutrelepont H, Kenis L, Van Nuffel J, Cloetens J, Vanderhoeft E, Vervoenen M. 2013. Additional contributions to the knowledge of the sediments, taphonomy, ichnofossils, bacteria, invertebrata, algae and plantae of the Sint Niklaas Phosphorite Bed in its type locality: Sint Niklaas (Eastern Flanders, Belgium). Part three: Vertebrata. Pp. 1-249 in: Herman J, ed., Découvertes géologiques, minéralogiques et paléontologiques en Belgique. Géominpal Belgica 5.3.

Hoffmann L. 1912. Zur Kenntnis des Neurocraniums der Pristiden und Pristiophoriden. Zoologische Jahrbücher, Abteilung für Anatomie und Ontogenie der Tiere 33: 239-360.

Holmgren N. 1941 Studies on the head in fishes. Part II. Comparative anatomy of the adult selachian skull, with remarks on the dorsal fins in sharks. Acta Zoologica 22: 1-100.

Hovestadt DC, Hovestadt-Euler M. 1995. Additions to the fauna of the Boom Clay Formation of Belgium (Rupelian, Oligocene). Taxonomic adjustments on the Scyliorhinidae and Rajoidei, discovery of a dasyatid species (Pisces, Chondrichthyes) and of a curculionid species (Insecta, Coleoptera). Pp. 261-282 in: Herman J, Van Waes H, eds, Elasmobranches et Stratigraphie. Belgian Geological Survey, Professional Paper 278.

Hubrecht AAW. 1876. Fische: Pisces. Pp. 1-32, 33-48 in: Bronn HG, ed., Klassen und Ordnungen des Thier-Reichs wissenschaftlich dargestellt in Wort und Bild (6)1. Leipzig/Heidelberg: Winter'sche Verlagshandlung.

Iselstöger H. 1937. Das Neurocranium von Rhina squatina und einige Bemerkungen über ihre systematische Stellung. Zoologische Jahrbücher, Abteilung für Anatomie und Ontogenie der Thiere 62: 349-394.

Iselstöger H. 1944. Ein Beitrag zur Kenntnis der Lebensweise von Rhina squatina. Verhandlungen der Zoologisch-Botanischen Gesellschaft in Wien 90-91: 77-82.

Jaekel O. 1890. Ueber die systematische Stellung und über fossile Reste der Gattung Pristiophorus. Zeitschrift der deutschen geologischen Gesellschaft 42: 86-120.

Jaekel O. 1891. Ueber die Gattung Pristiophorus. Archiv für Naturgeschichte 57: 15-48.

Jaekel O. 1898. Ueber die verschiedenen Rochentypen. Sitzungs-Berichte der Gesellschaft naturforschender Freunde zu Berlin 1898: 44-53.

Janssen AW. 1981. Molluskenfauna's en de stratigrafie van Oligocene afzettingen in een tweetal kleigroeven te Sint-Niklaas, Provincie Oost-Vlaanderen, België. Annalen van de Koninklijke Oudheidkundige Kring van het Land van Waas 84: 9-39.

Klug S, Kriwet J. 2013. Node age estimations and the origin of angel sharks, Squatiniformes (Neoselachii, Squalomorphii). Journal of Systematic Palaeontology 11: 91-110.

Laga P, Louwye S, Geets S. 2002. Paleogene and Neogene lithostratigraphic units (Belgium). Pp. 135-152 in: Bultynck $\mathrm{P}$, Dejonghe L, eds, Guide to a revised lithostratigraphic scale of Belgium. Geologica Belgica 4 (for 2001). 
Le Hon H. 1871. Préliminaires d'un mémoire sur les poissons tertiaires de Belgique. Bruxelles: Muquardt (Merzbach, successeur).

Leriche M. 1902. Les poissons paléocènes de la Belgique. Mémoires du Musée Royal d'Histoire naturelle 2: 1-48.

Leriche M. 1905. Les poissons éocènes de la Belgique. Mémoires du Musée Royal d'Histoire naturelle 3: 49-228.

Leriche M. 1908. Sur un appareil fanonculaire de Cetorhinus trouvé à l'état fossile dans le Pliocène d'Anvers. Comptes Rendus hebdomadaires des Séances de l'Academie des Sciences 146: 875-878.

Leriche M. 1909. Note préliminaire sur des poissons nouveaux de l'Oligocène belge. Bulletin de la Société belge de Géologie, de Paléontologie et d'Hydrologie 22: 378-384.

Leriche M. 1910. Les poissons oligocènes de la Belgique. Mémoires du Musée Royal d'Histoire naturelle 5: 229-363.

Leriche M. 1926. Les poissons néogènes de la Belgique. Mémoires du Musée Royal d'Histoire naturelle 32: 367-472.

Lesueur CA. 1818. Description of several new species of North American fishes. Journal of the Academy of Natural Sciences Philadelphia 1: 222-235, 359-368.

Linck HF. 1790. Versuch einer Eintheilung der Fische nach den Zähnen. Magazin für das Neueste aus der Physik und Naturgeschichte 6: 28-38.

Linnaeus C. 1758. Systema naturae per regna tria naturae, secundum classes, ordines, genera, species, cum characteribus, differentiis, synonymis, locis. Tomus I. Edition decima, reformata. Holmiae: Laurentius Salvius.

Maisey JG. 1983. Cranial anatomy of Hybodus basanus Egerton from the Lower Cretaceous of England. American Museum Novitates 2758: 1-64.

Maisey JG. 1985. Cranial morphology of the fossil elasmobranch Synechodus dubrisiensis. American Museum Novitates 2804: 1-28.

Maisey JG. 2007. The braincase in Paleozoic symmoriiform and cladoselachian sharks. Bulletin of the American Museum of Natural History 307: 1-122.

Marini TL. 1930. Nueve especie de pez ángel Rhina argentina n. sp. Physis (Buenos Aires) 10: 5-7.

Marini TL. 1936. Revisión de la familia «Squatinidae» en las aguas argentinas ( $\ll$ S. guggenheim» n. sp.). Physis (Buenos Aires) 12: 19-30.

Marquet R, Herman J. 2012. Reinvestigation of the invertebrate fauna of the Boom Clay Formation and the Ruisbroek Sand Member (Oligocene, Rupelian) of Belgium, with the description of a new lithostratigraphic unit: the Sint Niklaas Phosphorite Bed. Cainozoic Research 9: 101-120.

Martini E. 1971. Standard Tertiary and Quaternary calcareous nannoplankton zonation. Pp. 739-785 in: Farinacci A, ed., Proceedings of the Second Planktonic Conference (Roma) 2. Roma: Tecnoscienza.

Melouk MA. 1948. On the relation between the vertebral column and the occipital region of the chondrocranium in the Selachii and its phylogenetic significance. Publications of the Marine Biological Station Ghardaqa (Red Sea) 6: 45-51.

Molin R. 1860. Sullo scheletro degli Squali. Memorie dell'Istituto Reale Veneto di Scienze, Lettere ed Arti 8: 391-481.

Mollen FH. 2007. A new species of Abdounia (Elasmobranchii, Carcharhinidae) from the base of the Boom Clay Formation (Oligocene) in northwest Belgium. Geologica Belgica 10: 69-77.
Mollen FH. 2010. A partial rostrum of the porbeagle shark Lamna nasus (Lamniformes, Lamnidae) from the Miocene of the North Sea Basin and the taxonomic importance of rostral morphology in extinct sharks. Geologica Belgica 13: 61-76.

Mollen FH, Jagt JWM. 2012. The taxonomic value of rostral nodes of extinct sharks, with comments on previous records of the genus Lamna (Lamniformes, Lamnidae) from the Pliocene of Lee Creek Mine, North Carolina (USA). Acta Geologica Polonica 62: 117-127.

Mollen FH, Wintner SP, Iglésias SP, Van Sommeran SR, Jagt JWM. 2012. Comparative morphology of rostral cartilages in extant mackerel sharks (Chondrichthyes, Lamniformes, Lamnidae) using CT scanning. Zootaxa 3340: 29-43.

Müller J, Henle FGJ. 1837. Gattungen der Haifische und Rochen nach einer von ihm mit Hrn. Henle unternommenen gemeinschaftlichen Arbeit über die Naturgeschichte der Knorpelfische. Bericht über die zur Bekanntmachung geeigneten Verhandlungen der Königlichen Preussischen Akademie der Wissenschaften zu Berlin 2: 111-118.

Münster GG von. 1842. Beschreibungen einiger neuen Fische in den lithographischen Schiefern von Bayern. Beiträge zur Petrefactenkunde 5: 55-64.

Natanson LJ, Cailliet GM. 1990. Vertebral growth zone deposition in Pacific angel sharks. Copeia 1990: 1133-1145.

Noetling P. 1885. Die Fauna des samländischen Tertiärs. I Theil. Vertebrata, Crustacea und Vermes, Echinodermata. Abhandlungen zur geologischen Specialkarte von Preussen und den Thüringischen Staaten 5: 273-486.

Nolf D. 1988. Fossielen van België. Haaie- [sic] en roggentanden uit het Tertiair van België. Brussel: Koninklijk Belgisch Instituut voor Natuurwetenschappen.

Probst J. 1879. Beiträge zur Kenntniss der fossilen Fische aus der Molasse von Baltringen. Hayfische. Jahreshefte des Vereins für vaterländische Naturkunde in Württemberg 35: 127-191.

Qingwen M, Jinxiang S, Yuanding Z. 1986. A study on the neurocrania of some Chinese sharks. Acta Zoologica Sinica 32: 360-368.

Regan TC. 1906a. Descriptions of new or little known fishes from the coast of Natal. Annals of the Natal Government Museum 1: 1-6.

Regan TC. 1906b. Descriptions of some new sharks in the British Museum Collection. Annals and Magazine of Natural History (7)18: 435-440.

Regan TC. 1908. A collection of fishes from the coasts of Natal, Zululand, and Cape Colony. Annals of the Natal Museum 1: 241-255.

Reinecke T, Stapf H, Raisch M. 2001. Die Selachier und Chimären des unteren Meeressandes und Schleichsandes im Mainzer Becken. Palaeontos 1: 1-73.

Ridewood WG. 1921. On the calcification of the vertebral centra in sharks and rays. Philosophical Transactions of the Royal Society of London B210: 311-407.

Sauvage E, Herculais JK, 1885. Les poisons et les crustacés. Pp. 1-836 in: Brehm AE, ed., Les merveilles de la nature. Paris: JB Baillière et fils.

Shirai S. 1992a. Phylogenetic relationships of the angel sharks, with comments on elasmobranch phylogeny (Chondrichthyes, Squatinidae). Copeia 1992: 505-518.

Shirai S. 1992b. Squalean phylogeny, a new framework of "squaloid" sharks and related taxa. Sapporo: Hokkaido University Press. 
Stelbrink B, Rintelen T von, Cliff G, Kriwet J. 2010. Molecular systematics and global phylogeography of angel sharks (genus Squatina). Molecular Phylogenetics and Evolution 54: 395-404.

Steurbaut E. 1986. Late Middle Eocene to Middle Oligocene calcareous nannoplankton from the Kallo well, some boreholes and exposures in Belgium and a description of the Ruisbroek Sand Member. Mededelingen van de Werkgroep voor Tertiaire en Kwartaire Geologie 23: 49-83.

Steurbaut E. 1992. Integrated stratigraphic analysis of lower Rupelian deposits (Oligocene) in the Belgian basin. Annales de la Société géologique de Belgique 115: 287-306.

Steurbaut E, Herman J. 1978. Biostratigraphie et poissons fossiles de la Formation de l'Argile de Boom (Oligocène moyen du bassin belge). Géobios 11: 297-325.

Stohler R. 1945. Preparation of shark chondrocrania for class use. Science, new series 102: 403-404.

Storms R. 1894. Troisième note sur les poissons du terrain Rupelien. Bulletin de la Société belge de Géologie, de Paléontologie et d'Hydrologie, Mémoires 8: 67-82.

Underwood CJ. 2002. Sharks, rays and a chimaeroid from the Kimmeridgian (late Jurassic) of Ringstead, southern England. Palaeontology 45: 297-325.

Van Beneden PJ. 1873. Paléontologie des vertébrés. Pp. 353388 in: Van Bemmel ME, ed., Patria Belgica, Encyclopédie nationale ou exposé méthodique de toutes les connaissances relatives à la Belgique ancienne et moderne, physique, sociale et intellectuelle, 1. Bruxelles: Bruylant-Christophe and Cie.

Vandenberghe N. 1978. Sedimentology of the Boom Clay (Rupelian) in Belgium. Verhandelingen van de Koninklijke Akademie voor Wetenschappen, Letteren en Schone Kunsten van België 40: 1-137.

Vandenberghe N, Herman J, Steurbaut E. 2002. Detailed analysis of the Rupelian Ru-1 transgressive surface in the type area (Belgium). Pp. 67-81 in: Gürs K, ed., Northern European Cenozoic Stratigraphy. Proceedings of the 8th Biannual Meeting of the RCNNS/RCNPS, Flintbek.

Vandenberghe N, Laga P. 1986. The septaria of the Boom Clay (Rupelian) in its type area in Belgium. Aardkundige Mededelingen 3: 229-238.

Vandenberghe N, Laga P, Steurbaut E, Hardenbol J, Vail PR. 1998. Tertiary sequence stratigraphy at the southern border of the North Sea basin. Pp. 119-154 in: Graciansky PC, Hardenbol J, Jacquin T, Vail PR, eds, Mesozoic and Cenozoic sequence stratigraphy of European basins. SEPM Special Publications 60.

Vaz DFB, Carvalho MR de. 2013. Morphological and taxonomic revision of species of Squatina from the southwestern Atlantic Ocean (Chondrichthyes: Squatiniformes: Squatinidae). Zootaxa 3695: 1-81.

Vélez-Zuazo X, Agnarsson I., 2011 Shark tales: a molecular species-level phylogeny of sharks (Selachimorpha, Chondrichthyes). Molecular Phylogenetics and Evolution 58: 207-217.

Vooren CM, Silva KG da. 1991. On the taxonomy of the angel sharks from southern Brazil, with the description of Squatina occulta sp. n. Revista Brasileira de Biologia 51: 589-602.

Weiler W. 1922. Beiträge zur Kenntnis der tertiären Fische des Mainzer Beckens I. Abhandlungen der Hessischen Geologischen Landesanstalt zu Darmstadt 6: 69-135.

Welton BJ. 2013. A new archaic basking shark (Lamniformes: Cetorhinidae) from the Late Eocene of western Oregon, U.S.A., and description of the dentition, gill rakers and vertebrae of the Recent basking shark Cetorhinus maximus (Gunnerus). New Mexico Museum of Natural History and Science, Bulletin 58: 1-48.

White EI, Moy-Thomas JA. 1941. Notes on the nomenclature of fossil fishes. Part III. Homonyms M-Z. Annals and Magazine of Natural History (11)7: 395-400.

Whitley GP. 1940. The fishes of Australia, Part 1. The sharks, rays, devil-fish, and other primitive fishes of Australia and New Zealand. Sydney: Royal Zoological Society of New South Wales.

Winchell CJ, Martin AP, Mallatt J. 2004. Phylogeny of elasmobranchs based on LSU and SSU ribosomal RNA genes. Molecular Phylogeny and Evolution 31: 214-224.

Winkler TC. 1880. Note sur quelques dents de poissons fossiles de l'Oligocène inférieur et moyen du Limbourg. Archives $d u$ Musée Teyler 5: 73-84.

Received: 24 April 2015

Revised and accepted: 12 November 2015

Published online: 24 March 2016

Editor: R. Vonk 


\section{Appendix 1}

Anatomical abbreviations

II optic nerve foramen

IX glossopharygeal nerve foramen

$\mathrm{X}$ vagus nerve foramen

AOC antorbital cartilage

AF anterior fontanelle

BAV basiventral process

BP basal plate

CC cranial cavity

CR cranial roof

EC epiotic crest

EF endolymphatic fossa

ELF endolymphatic foramen

FM foramen magnum

FNA articular foramen for neural arch

GB glossopharygeal base

HF hyomandibular facet

ICF internal carotid artery foramen

LC lateral commissure

LPOP lower postorbital process

NA nasal aparture

$\mathrm{NC}$ nasal capsule

OC otic capsule
OCC occipita condyle

OEC otic external canal

OG orbital groove

$\mathrm{OHC}$ occipital hemicentrum

OP occipital process

OW orbital wall

PCF precerebral fossa

PEP preorbital process

POC preorbital canal

POP postorbital process

POW postorbital wall

PP pterotic process

RP rostral projection

ROS rostrum

ROSt rostral teeth

SBC suborbital crest

SF supraorbital flange

SPC supraorbital crest

UPOP upper postorbital process

$\mathrm{VC}$ posterior vein foramen

VCE vertebral centre

VHJ ventral margin of hyoid junction 


\section{Appendix 2}

\section{List of comparative Recent material}

This list comprises both fresh, complete specimens as well as published illustrations of chondrocrania of both Pristiophorus and Squatina, all examined for the present study.

Squatina Duméril, 1806

\section{Squatina sp.}

Illustrations: de Carvalho et al. (2012: Fig. 1); Gegenbaur (1872: Pl. 5, Fig. 6; Pl. 11, Fig. 2; Pl. 12, Fig. 4), reillustrated by Hubrecht (1876: Pl. 5, Figs 10-13; non Molin, 1860, as erroneously stated by de Carvalho et al., 2008); Sauvage and D'Herculais (1885: Figs 22-23, 208-209).

Squatina aculeata Cuvier, 1829

Illustration: Capapé and Roux (1980: Fig. 1B).

Squatina africana Regan, 1908

Fresh material: 2 specimens, ERB 0968 (= KZNSBDUR 12073), male, $810 \mathrm{~mm}$ TL; ERB 0971 (= KZNSBDUR 12074), male, $820 \mathrm{~mm}$ TL, both 6 August 2012, caught in protective gill nets off Durban, South Africa, southwest Indian Ocean.

Squatina argentina (Marini, 1930)

Illustrations: de Carvalho et al. (2012: Figs 2B, 3B, 4B, 6B); Vaz and de Carvalho (2013: Figs 43AD, 44C).

Squatina australis Regan, 1906b

Fresh material: 1 specimen, ERB 0514, male, $865 \mathrm{~mm}$ TL, April 2010, caught 18 miles off Bunbury, Western Australia, southeast Indian Ocean.

Squatina californica Ayres, 1859

Illustrations: Compagno (1973: Fig. 2E), redrawn by Cappetta (1987: Fig. 3D); de Carvalho et al. (2008: Fig. $4 \mathrm{~A}-\mathrm{B})$.

Squatina dumeril Lesueur, 1818

Fresh material: 1 specimen, ERB 1026, female, 715 $\mathrm{mm}$ TL, 17 March 2013, co-ordinates 37²3,9'N, $74^{\circ} 28,8^{\prime} \mathrm{W}$ (begin haul), $37^{\circ} 23,1^{\prime} \mathrm{N}, 74^{\circ} 28,3^{\prime} \mathrm{W}$ (end haul), northwest Atlantic Ocean.

Illustrations: Claeson and Hilger (2011: Fig. 3B-C).
Squatina guggenheim Marini, 1936

Fresh: 4 specimens, ERB 0831, male, 830 mm TL; ERB 0853, female, $880 \mathrm{~mm}$ TL, both 16 April 2010; ERB 0881 (= IRScNB 24604), female, $820 \mathrm{~mm}$ TL; ERB 899 (= IRScNB 24603), female, $840 \mathrm{~mm}$ TL, both 16 March 2010, all caught off Rocha Department, Uruguay, southwestern Atlantic Ocean.

Illustrations: de Carvalho et al. (2012: Figs 2A, 3A, 4A, 5, 6A); Vaz and de Carvalho (2013: 42A-D, 44B).

Squatina japonica Bleeker, 1858

Illustrations: Shirai (1992b: Pl. 13, Figs A-C; Pl. 21, Fig. C); Qingwen et al. (1986: Fig. 9D).

Squatina nebulosa Regan, 1906b

Illustrations: Shirai (1992a: Fig. 2C-D).

Squatina occulta Vooren and da Silva, 1991

Illustrations: de Carvalho et al. (2012: Figs 2C, 3C, 4C, 6C); Vaz and de Carvalho (2013: Figs 41A-D, $44 \mathrm{~A})$.

Squatina oculata Bonaparte, 1840

Illustration: Hamdy (1960: Fig. 1.2); Capapé and Roux (1980: Fig. 1C).

Squatina squatina (Linnaeus, 1758), type species

Fresh material: 1 specimen, ERB 1029, male, 1395 $\mathrm{mm}$ TL, 16 January 2012, co-ordinates $50^{\circ} 55^{\prime} \mathrm{N}$, $05^{\circ} 00^{\prime} \mathrm{W}$, Irish Sea.

Illustrations: Molin (1860: Pl. 7, Fig. 4; Pl. 8, Figs 1-2), re-illustrated by de Carvalho et al. (2008: Fig. 5A-C, G); Iselstöger (1937: Figs 3-4, Pl. 6); Holmgren (1941: Figs 33-35, 36A), reillustrated by Berg (1958: Fig. 45); Melouk (1948: Fig. 2), Casier (1966: Fig. 6A-B); Capapé and Roux (1980: Fig. 1A); Claeson and Hilger (2011: Fig. A). 
Pristiophorus Müller and Henle, 1837

Pristiophorus sp.

Illustrations: Jaekel (1890: Figs 2-3), reillustrated by Jaekel (1891: Figs 2-3); Hoffmann (1912: Fig. F); Whitley (1940: Fig. 11); Compagno (1977: Fig. 4E-H); Shirai (1992a: Fig. 9A).

Pristiophorus japonicus Günther, 1870

Illustrations: Hoffmann (1912: Pl. 15, Figs 18-20; Pl. 16, Fig. 28); Holmgren (1941: Figs 58-59); Compagno (1973: Fig. 2D), redrawn by Cappetta (1987: Fig. 3C).
Pristiophorus nudipinnis Günther, 1870

Fresh: 1 specimen, ERB 1058, female, 830 mm TL, 17 September 2014, caught by gill net, east of Adventure Bay/Fluted Cape, co-ordinates $42^{\prime} 21^{\circ} \mathrm{S}, 147^{\circ} 26^{\prime} \mathrm{E}$, depth 65 metres, Tasman Sea.

Illustrations: Hoffmann (1912: Pl. 20, Figs 57-59; Pl. 22, Figs 64-68; Pl. 23, Figs 69-74; Pl. 24, Figs 75-80); Shirai (1992b: Pl. 14, Figs A-C). 


\section{Appendix 3}

\section{Updated species list}

The present elasmobranch faunal list from the Sint Niklaas Phosphorite Bed (Rupelian, Oligocene) at the SVK clay pit near Sint-Niklaas (Oost-Vlaanderen, Belgium) was updated on the basis of van den Bosch (1981), Mollen (2007) and ERB collections (FHM, pers. obs.). Systematics follow Cappetta (2006, 2012) and Welton (2013).

\section{HEXANCHIFORMES}

Notorynchus primigenius (Agassiz, 1835)

SQUALIFORMES

Squalus alsaticus Andreae, 1892

SQUATINIFORMES

Squatina sp.

\section{HETERODONTIFORMES}

Heterodontus sp.

\section{LAMNIFORMES}

Alopias exigua (Probst, 1879)

Alopias latidens (Leriche, 1909)

Araloselachus cuspidatus (Agassiz, 1843)

Carcharias acutissima (Agassiz, 1843)

Isurolamna gracilis (Le Hon, 1871)

Isurus flandricus (Leriche, 1910)

Keasius parvus (Leriche, 1908)

Lethenia vandenbroecki (Winkler, 1880)

Otodus angustidens (Agassiz, 1835)

CARCHARHINIFORMES

Abdounia belselensis Mollen, 2007

Carcharhinus elongatus (Leriche, 1910)

Bythaelurus steurbauti Hovestadt and Hovestadt-

Euler, 1995

Physogaleus latus (Storms, 1894)

RAJIFORMES

Raja casieri Steurbaut and Herman, 1978

MYLIOBATIFORMES

Dasyatis sp.

Myliobatis sp. 